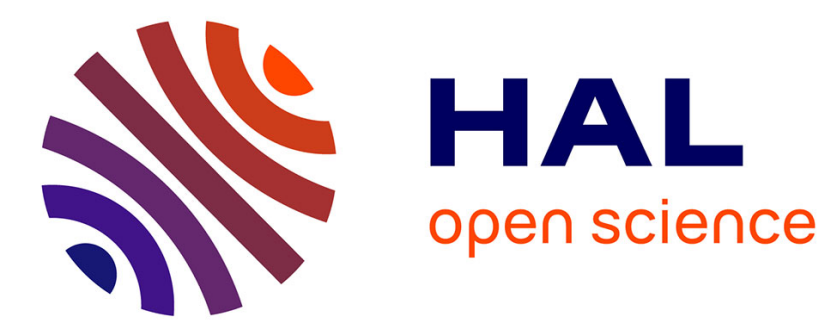

\title{
Tropical transition of a Mediterranean storm by jet crossing
}

Jean-Pierre Chaboureau, Florian Pantillon, Dominique Lambert, Evelyne Richard, Chantal Claud

\section{To cite this version:}

Jean-Pierre Chaboureau, Florian Pantillon, Dominique Lambert, Evelyne Richard, Chantal Claud. Tropical transition of a Mediterranean storm by jet crossing. Quarterly Journal of the Royal Meteorological Society, 2012, 138 (664), pp.596-611. 10.1002/qj.960 . hal-01006505

\section{HAL Id: hal-01006505 \\ https://hal.science/hal-01006505}

Submitted on 8 Feb 2022

HAL is a multi-disciplinary open access archive for the deposit and dissemination of scientific research documents, whether they are published or not. The documents may come from teaching and research institutions in France or abroad, or from public or private research centers.
L'archive ouverte pluridisciplinaire HAL, est destinée au dépôt et à la diffusion de documents scientifiques de niveau recherche, publiés ou non, émanant des établissements d'enseignement et de recherche français ou étrangers, des laboratoires publics ou privés.

\section{다)(1) $(5$}

Distributed under a Creative Commons Attribution - NonCommerciall 4.0 International 


\title{
Tropical transition of a Mediterranean storm by jet crossing
}

\author{
Jean-Pierre Chaboureau, ${ }^{\text {ał }}$ Florian Pantillon, ${ }^{\mathrm{a}}$ Dominique Lambert, ${ }^{\mathrm{a}}$ Evelyne Richard ${ }^{\mathrm{a}}$ \\ and Chantal Claud ${ }^{\mathrm{b}}$ \\ ${ }^{a}$ Laboratoire d'Aérologie, Université de Toulouse and CNRS, Toulouse, France \\ ${ }^{\mathrm{b}}$ Laboratoire de Météorologie Dynamique, Ecole Polytechnique, Palaiseau, France
}

${ }^{*}$ Correspondence to: J.-P. Chaboureau, Laboratoire d’Aérologie, Observatoire Midi-Pyrénées, 14 av. Belin, F-31400

Toulouse, France. E-mail: jean-pierre.chaboureau@aero.obs-mip.fr

\begin{abstract}
The tropical transition of a Mediterranean storm that occurred on 26 September 2006 over southeastern Italy is investigated. The explosive development classified this cyclone as a bomb and its full-tropospheric warm core as a tropical-like storm or medicane. Forecasts at different scales were analysed to identify the key mechanisms in the explosive development of the medicane. At $108 \mathrm{~h}$ lead time, the European Centre for Medium-Range Weather Forecasts (ECMWF) failed to predict the medicane and the associated upper-level trough downstream of the ex-tropical cyclone Helene during its extratropical transition. At shorter range, forecasts by both ECMWF and Action de Recherche Petite Echelle Grande Echelle (ARPEGE) increasingly improved with decreasing lead times. The depth of the medicane was missed, however, probably because of the too low resolution with respect to the $60 \mathrm{~km}$ diameter cyclone. Forecasts at kilometre scale were run using the mesoscale model Meso- $\mathrm{NH}$ and verified against in situ and satellite observations. The Meso-NH forecasts were found to be very sensitive to the initial conditions. Reduced static stability at the southern tip of the upper-level trough determined the convective activity around the pre-existing mesocyclone. The medicane was then formed only if enough vertically developed convection was further enhanced by the jet-induced upward forcing. Otherwise, no tropical transition of the mesocyclone was predicted. This study shows the role of an upper-level jet in explosively deepening a mesocyclone into a tropical storm.
\end{abstract}

Key Words: tropical transition; Mediterranean storm; jet crossing; mesoscale modelling

\section{Introduction}

The Mediterranean basin is a region known for its frequent cyclonic activity. Its geographical location between the Subtropics and the midlatitudes, the complex orography surrounding the Mediterranean Sea, and the large reservoir of sometimes warm water contribute to the formation of a broad continuum of cyclones, from shallow, warmcore to deep, cold-core storms (Campins et al., 2006). Satellite observations show a majority of cloud systems at the mesoscale, only a fraction being associated with an upper-level anomaly and preferentially during the cold season (Chaboureau and Claud, 2006), while deep convection has been sensed over the sea mostly during autumn (Funatsu et al., 2009). Among the Mediterranean cyclones accompanied by upper-level anomalies and deep convection, about 15 mesocyclones have been observed over the last 20 years, preferentially in autumn (Fita et al., 2007). They share some similarities with tropical cyclones and a number of case studies have been made on these hurricanelike cyclones or medicanes (Mediterranean 'hurricanes'; Lagouvardos et al., 1999; Pytharoulis et al., 2000; Reale and 
Atlas, 2001; Homar et al., 2003; Fita et al., 2007; Moscatello et al., 2008a, 2008b; Davolio et al., 2009; Claud et al., 2010; McTaggart-Cowan et al., 2010; among others). A medicane exhibits a clearly defined eye, quasi-circular cloud patterns, strong surface winds sometimes reaching the intensity of a tropical storm, deep convection and the presence of a warm core. The lifetime of a medicane mostly varies between 6 and $8 \mathrm{~h}$ for the mature stage with the presence of an eye, and lasts up to 5 days if all the cyclonic activity is considered. Medicanes usually dissipate when they make landfall.

During the initiation phase, the medicane is born from a pre-existing vortex either caused by the lee effect of the surrounding mountains (e.g. Homar et al., 2003; Moscatello et al., 2008b) or formed at the edge of a wider cyclone (e.g. Lagouvardos et al., 1999; Pytharoulis et al., 2000). The vortex is accompanied by deep convection and a deep, cutoff, cold core is usually observed at mid-upper tropospheric levels (e.g. Reale and Atlas, 2001; Fita et al., 2007), which triggers the convective instability (e.g. Reale and Atlas, 2001; Homar et al., 2003; Pytharoulis et al., 2000). During the mature phase, the coupled interaction between deep convection and sea surface fluxes is seen as the central mechanism in the maintenance of the medicane. The importance of air-sea interaction has been evidenced in a number of sensitivity experiments in which the surface fluxes and convection were switched off (Pytharoulis et al., 2000; Homar et al., 2003; Moscatello et al., 2008a; Davolio et al., 2009). However, experiments with an axisymmetric model run for the observed environment of seven medicanes without any baroclinicity showed longer life cycles than were actually observed for the medicanes (Fita et al., 2007). This result suggests that deep convection cannot, alone, explain the growth of real medicanes and points out the importance of the baroclinic environment in which medicanes often form.

A key element in the intensification of the medicane is the transformation of the extratropical disturbance into a tropical-like storm. This transformation is named a tropical transition (Davis and Bosart, 2004) (by contrast with extratropical transition; Jones et al., 2003), and results in an extratropical disturbance giving a tropical cyclone. Mostly studied over the Atlantic basin, extratropical disturbances that transform into tropical cyclones are characterized by an environment that is initially sheared. Convection is seen as the main agent of the tropical transition. It reduces the shear with the upper-tropospheric outflow and leads to diabatic redistribution of potential vorticity $(\mathrm{PV})$. The way convection becomes organized in such systems is a part of the large continuum of tropical transitions that remains to be explored. This study will describe jet crossing as a new mechanism for the transformation of a shallow, warm core into a medicane.

Jet crossing refers to the passage of a low-level anomaly from one side of an upper-level jet to another. Because the upper-level forcing generally changes with the side of the jet, it can impact cyclogenesis enough to produce explosive development if there is interaction between dynamical and diabatic processes (Uccellini, 1986). In the classic four-quadrant conceptual model for a straight jet streak, ageostrophic circulations are created in response to geostrophic balance of the upper-level jet. In particular, they are accompanied by ascending motions in the right-entrance and left-exit regions of the jet streak. The conceptual model applied to the straight jet is, however, modified because of flow curvature, thermal advection and the position of the jet streak within the synoptic-scale flow pattern (Pyle et al., 2004). These localized effects, in causing upper-level jet kinematic signatures to depart from the classic fourquadrant conceptual model, can be diagnosed using the omega equation. Such a diagnostic was employed here to show the role of the upper-level forcing in the explosive development of the medicane during its transition from the anticyclonic to the cyclonic shear side of the jet.

The medicane that we considered affected southeastern Italy on 26 September 2006. A mean-sea-level-pressure (MSLP) minimum of $986 \mathrm{hPa}$ and wind gusts exceeding $40 \mathrm{~m} \mathrm{~s}^{-1}$ (78 kt) were recorded (Moscatello et al., 2008b), the most intense values ever registered for a medicane. It was also the medicane that experienced the most rapid development. Although the low formed as early as 24 September, we focus on the intensification phase over the Ionian Sea, when the cyclone took on the characteristics of a tropicallike cyclone on the morning of 26 September. Based on numerical experiments, Moscatello et al.(2008a) and Davolio et al.(2009) attributed the rapid deepening of the cyclone to its interaction with convection enhanced by the orography of Calabria (a small lee cyclogenesis was noted to occur east of Calabria in this phase; Moscatello et al.,2008a; Davolio et al., 2009). Although they noted that an upper-level PV anomaly moved close to the vicinity of the mesocyclone during this phase, they did not explore its role further. In the following, we will examine the relationship between the medicane and the upper-level PV anomaly.

In this study, a number of forecasts of global and limited-area models are compared to better understand the interaction between the growing surface cyclone and the upper-level trough. The forecasts from the European Centre for Medium-Range Weather Forecasts (ECMWF) global model are first examined over a domain covering the North Atlantic and the western Mediterranean basin. This synoptic perspective highlights the intrinsic relationship between the medicane, the upper-level trough and, further upstream, the ex-tropical cyclone Helene, which experienced an extratropical transition. Short-range forecasts from the Action de Recherche Petite Echelle Grande Echelle (ARPEGE) and ECMWF models are then examined. To identify any eventual tropical transition, they are projected into the cyclone phase space (Hart, 2003), a continuum describing the broad evolution of all cyclone types (tropical, extratropical, subtropical, and hybrid) and the transitions from one to another. Because of the mesoscale size of the medicane, numerical experiments were performed at kilometre scale. As in Argence et al. (2008), a simple method consisting of building different atmospheric states by shifting the initialization time was employed to generate two sets of perturbed initial conditions from ARPEGE and ECMWF. The impact of initial-condition uncertainties on the evolution of the medicane allows the key mechanisms in play during the tropical transition to be stressed, in particular the explosive development of the medicane by jet crossing.

The paper is organized as follows. Section 2 gives an overview of the case study. Section 3 presents a brief analysis of the ECMWF and ARPEGE forecasts of the medicane at short and medium ranges. Section 4 describes the mesocale forecasts performed with the Meso-NH model. Section 5 concludes the paper. 

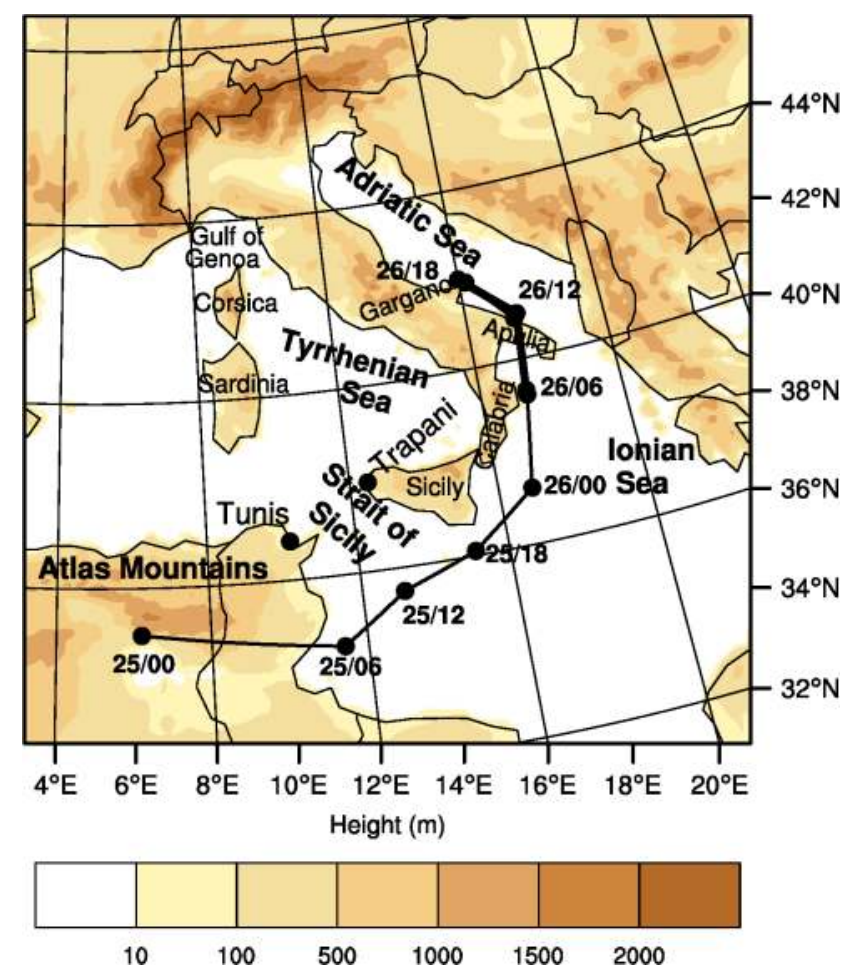

Figure 1. Topography $(\mathrm{m})$ of $8 \mathrm{~km}$ domain used for the Meso-NH experiments. The line shows the track of the mesocyclone as derived from ECMWF operational analyses every $6 \mathrm{~h}$ from 25 September 2006 at 0000 UTC to 26 September 2006 at 1800 UTC. Dates and times for the track are given as date/hour (UTC). The thick part of the line corresponds to the track of the medicane. This figure is available in colour online at wileyonlinelibrary.com/journal/qj

\section{Overview of the case study}

The case under investigation in this study (see trajectory on Figure 1) was somewhat unusual, in the sense that the inland movement of the medicane made rather good observation of its characteristics possible (the area affected by the medicane was covered by two radars and a high-resolution surface station network; Moscatello et al., 2008b). This unique dataset combined with the strong intensity of the medicane motivated a number of studies using numerical experiments (Moscatello et al., 2008a; Davolio et al., 2009; Miglietta et al., 2011; Laviola et al., 2011) and satellite observations (Claud et al., 2010; Conte et al., 2011). The overview of the case given below is based on these previous studies.

The mesoscale system originated on 24 September 2006 at noon as an orographic cyclone on the lee side of the Atlas Mountains. Favourable conditions were further created by a baroclinic system deepening over the Tyrrhenian Sea. At 0600 UTC on 25 September, the relatively large orographically generated cyclone reached the Strait of Sicily, where it deepened due to convection produced along a cold front moving eastward. At that time, it became a much smaller-scale cyclone. The cyclone subsequently moved northeastwards. At 0000 UTC on 26 September, the low entered the Ionian Sea, where it further deepened by $8 \mathrm{hPa}$ in $6 \mathrm{~h}$ according to the ECMWF analysis. At 0900 UTC, the now medicane crossed the Salentine peninsula. Wind gusts exceeding $40 \mathrm{~m} \mathrm{~s}^{-1}$ were measured at Galatina airport $\left(40.2^{\circ} \mathrm{N}, 18.1^{\circ} \mathrm{E}\right)$, and several surface stations recorded a sharp decrease in the MSLP, down to $986 \mathrm{hPa}$. Based on satellite measurements and ground observations, the diameter of the eye of the cyclone was estimated at $60 \mathrm{~km}$.

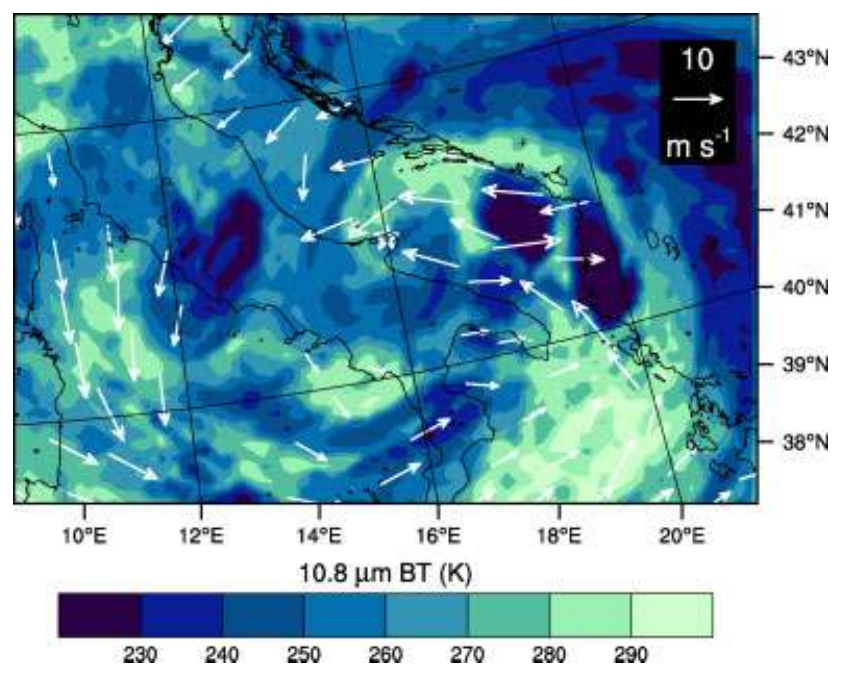

Figure 2. $10.8 \mu \mathrm{m} \mathrm{BT}$ (K, shading) and surface wind (vectors) obtained from MSG and QuikSCAT observations on 25 September 2006 at 1700 and 1654 UTC, respectively. The white star gives the position of the medicane as estimated by Moscatello et al. (2008a). This figure is available in colour online at wileyonlinelibrary.com/journal/qj

At 0945 UTC, the medicane moved over the Adriatic Sea, where both surface fluxes and latent heat release sustained its intensity (as shown by sensitivity experiments done by previous studies cited above), following an arc-shaped trajectory, and still associated with low values of MSLP. At 1700 UTC, the cyclone made landfall on the Gargano promontory $\left(41.7^{\circ} \mathrm{N}, 15.7^{\circ} \mathrm{E}\right)$, with cloud cover cyclonically rolling to the east of the medicane and surface wind of more than $18 \mathrm{~m} \mathrm{~s}^{-1}$ to the north (Figure 2). At 1715 UTC the MSLP in Vico del Gargano reached the minimum value of $988 \mathrm{hPa}$. Then, the cyclone weakened rapidly to finally merge with the main low-pressure system, still located over the Tyrrhenian Sea.

Although no sustained wind values were reported in the aforementioned studies, the record gust of $40 \mathrm{~m} \mathrm{~s}^{-1}$ suggests that sustained wind speed may not have reached the hurricane-level intensity of $33 \mathrm{~m} \mathrm{~s}^{-1}$, but could classify the medicane as a tropical storm. This suggestion is further supported by the absence of precipitation near the MSLP minimum (the eye of the cyclone) and a circle of precipitation around it observed by radar from $40^{\circ} \mathrm{N}, 18^{\circ} \mathrm{E}$ at 0900 UTC on 26 September. Maximum reflectivity values of about $45 \mathrm{dBZ}$ (corresponding to $24 \mathrm{~mm} \mathrm{~h}^{-1}$ ) were recorded by the radar during the passage of the medicane and a maximum of $120 \mathrm{~mm}$ of rainfall was observed at the Crispiano station $\left(40.6^{\circ} \mathrm{N}, 17.4^{\circ} \mathrm{E}\right)$ during the transit of the medicane over the area.

\section{Large-scale forecasts}

The medicane forecast was investigated at short range by Davolio etal. (2009) on the basis of two regional forecasting chains for which initial and boundary conditions were provided by the Global Forecast System-National Centers for Environmental Prediction analyses and forecasts starting at 0000 UTC 25 September. Sensitivity experiments were performed using ECMWF analysis and forecasts. Their results show a strong sensitivity to the initial and boundary conditions, simulations starting at 1200 UTC on 25 September presenting better forecasts than those starting at 0000 UTC on 25 September. It was also found that the 

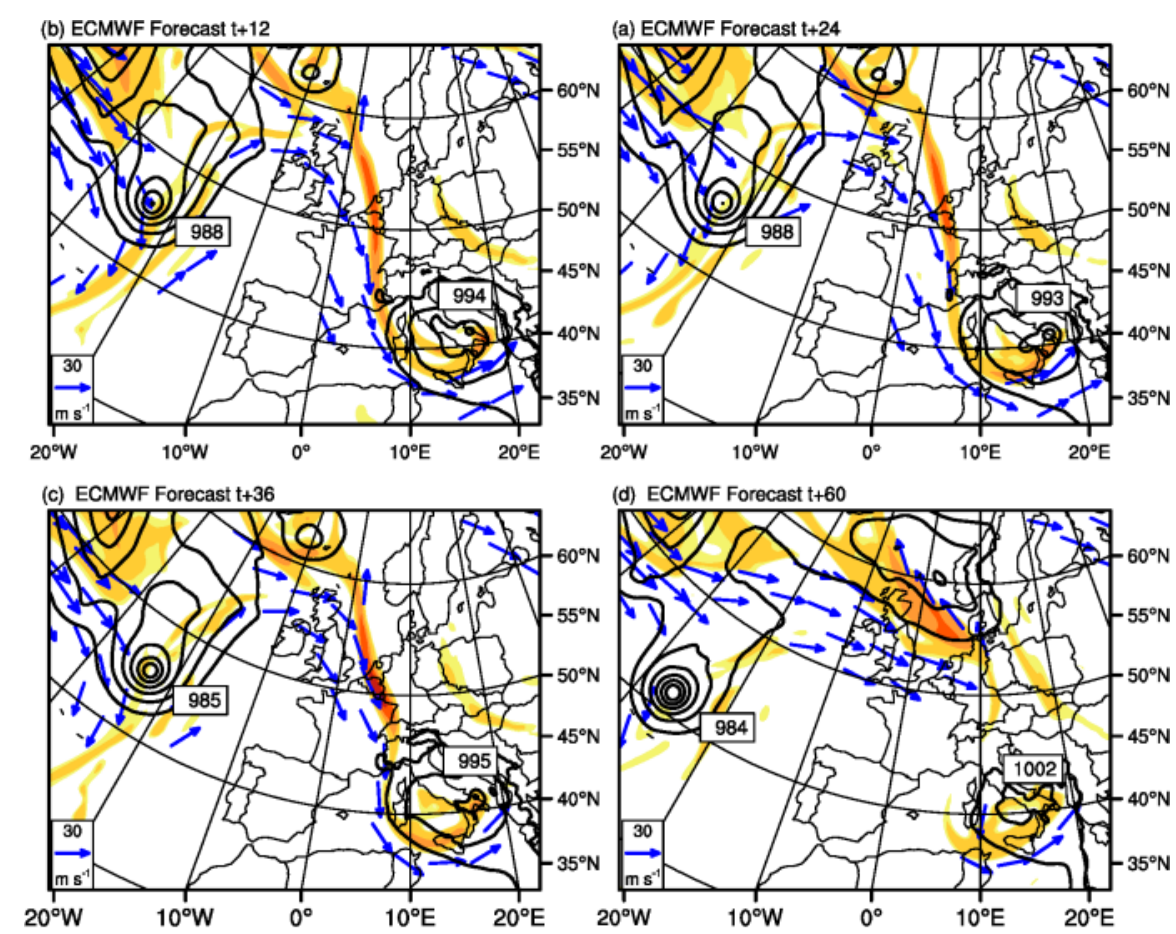

(d) ECMWF Forecast $t+60$

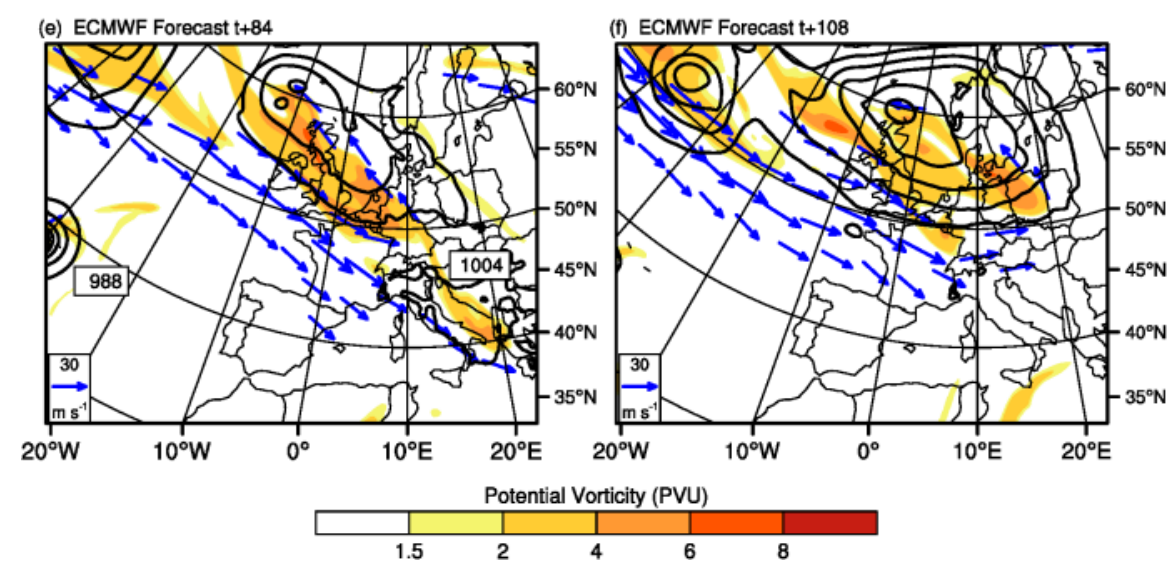

Figure 3. ECMWF forecasts at $1200 \mathrm{UTC}$ on 26 September 2006: PV at $300 \mathrm{hPa}$ (shaded, PVU $=10^{-6} \mathrm{~K} \mathrm{~m}^{-2} \mathrm{~s}^{-1} \mathrm{~kg}^{-1}$ ), wind at $300 \mathrm{hPa}$ (vectors, for winds larger than $30 \mathrm{~m} \mathrm{~s}^{-1}$ ), and mean sea-level pressure (solid lines, every $4 \mathrm{hPa}$ between $976 \mathrm{and} 1008 \mathrm{hPa}$ ). Forecasts are at (a) $t+12$, (b) $t+24$, (c) $t+36$, (d) $t+60$, (e) $t+84$, and (f) $t+108$. The figures (when applicable) indicate the local MSLP minima over the North Atlantic Ocean and the Mediterranean Sea associated with the ex-tropical cyclone Helene and the medicane, respectively. This figure is available in colour online at wileyonlinelibrary.com/journal/qj

limited-area models provided a much more accurate simulation of the cyclone in terms of both intensity and trajectory than the global models.

The predictability of the medicane is re-examined from a broader perspective here, using short to medium ranges. Results valid at 1200 UTC on 26 September 2006 are shown for ECMWF forecasts with lead times from 12 to $36 \mathrm{~h}$ every $12 \mathrm{~h}$ and from 60 to $108 \mathrm{~h}$ every $24 \mathrm{~h}$ (Figure 3). The poorest forecast was the $108 \mathrm{~h}$ one starting at $0000 \mathrm{UTC}$ on 22 September. The centre of the ex-tropical cyclone Helene was outside the domain, with no low-level cyclone or upperlevel trough over the Mediterranean. Every forecast except the $108 \mathrm{~h}$ one showed an upper-level trough over the Mediterranean and two local minima in the MSLP: one over the North Atlantic Ocean and a low centred over southeastern Italy. These forecasts differed substantially in the location of Helene (but they agreed with an MSLP of less than $990 \mathrm{hPa}$ ), the depth of the Mediterranean low (the MSLP minimum ranged between 993 and $1004 \mathrm{hPa}$ ), and the connection of the upper-level trough over the Mediterranean with the upstream flow over the Atlantic.

The $12 \mathrm{~h}, 24 \mathrm{~h}$, and $36 \mathrm{~h}$ forecasts showed a trough extending from the North Sea to the Mediterranean, with the southern tip rolling cyclonically over Sicily. A Mediterranean cyclone was forecasted with an MSLP minimum of less than $995 \mathrm{hPa}$ over southeastern Italy and the ex-hurricane Helene was located well. These short-term forecasts clearly differ from the medium-range forecasts, which did not predict the upper-level trough over the Mediterranean correctly. The $60 \mathrm{~h}$ forecast featured an upper-level cut-off low over the Tyrrhenian Sea and the $84 \mathrm{~h}$ forecast had a straight upperlevel trough ending further to the east over the Adriatic Sea. In addition, the ex-hurricane Helene was predicted too far to the southwest. The wrong location of Helene together with the more zonal direction taken by the Atlantic upper-level jet at $10^{\circ} \mathrm{W}$ suggest an incorrect prediction of the extratropical transition of Helene. This resulted in a weaker building of the downstream ridge centred over the British Isles, thus a weaker stretching applied to the trough over western 
Europe and the Mediterranean, and the underestimation of the deepening of the low-level cyclone over Italy, with an MSLP minimum remaining larger than $1001 \mathrm{hPa}$.

The reduced predictability of the medicane is illustrative of the impact of the extratropical transition on the midlatitude flow and the associated sensitivity of cyclogenesis in the downstream region. Such a reduction has been shown recently in the framework of operational ensemble systems (Harr et al., 2008; Anwender et al., 2008). Based on idealized scenarios, Riemer et al. (2008) and Riemer and Jones (2010) have demonstrated the sensitivity of the downstream flow to the evolution of the extratropical transition, in particular in the formation and amplification of the ridge-trough couplet at upper level. Here, the extratropical transition of Helene occurred between 22 and 25 September, a period from which the upper-level trough was poorly predicted.

The predictability of the medicane was further described at short range with ARPEGE (ECMWF) forecasts starting at 0000 and 1200 UTC on 25 September, hereafter called ARP00 and ARP12 (ECM00 and ECM12), respectively. The ECMWF forecasts were run at T799 spectral truncation (which corresponds to a horizontal resolution of $25 \mathrm{~km}$ ) and with 91 levels (top at $0.01 \mathrm{hPa}$ ), while ARPEGE has a stretched grid with a horizontal resolution from $23 \mathrm{~km}$ over France to $133 \mathrm{~km}$ on antipode and 41 vertical levels (top at $1 \mathrm{hPa}$ ). The tracks of the forecast cyclone from 1200 UTC on 25 September to 1800 UTC on 26 September are shown in Figure 4. The tracks are within $1^{\circ}$ of longitude and latitude-too far southwest compared to the best-estimate analysis performed by Moscatello et al. (2008b). The MSLP minimum decreased significantly with time from 0000 UTC on 26 September when the low was over the Ionian Sea.

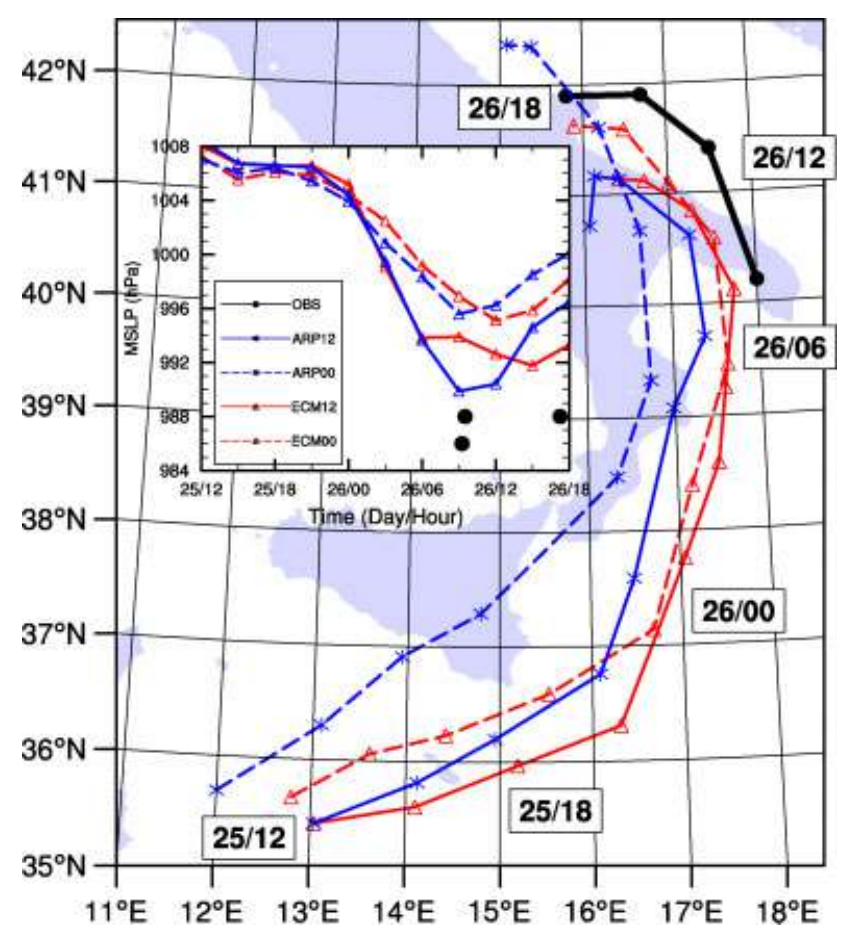

Figure 4. Track of the Mediterranean cyclone for the best-estimate analysis (dots, adapted from Moscatello et al., 2008a), the ARPEGE (asterisks) and ECMWF (triangles) forecasts. The track is every $3 \mathrm{~h}$ from 0900 to 1800 UTC on 26 September for the analysis and from 1200 UTC on 25 September to 1800 UTC on 26 September for the forecasts. The inset shows the time evolution of MSLP minimum; the black dots are values recorded at stations over land (Moscatello et al. 2008b). This figure is available in colour online at wileyonlinelibrary.com/journal/qj
The lowest values were reached by the forecasts starting on 1200 UTC (990 and $992 \mathrm{hPa}$ by ARP12 and ECM12 respectively) compared to their counterparts starting at 0000 UTC (MSLP was above $995 \mathrm{hPa}$ ). The $986 \mathrm{hPa}$ measured over the Salentine peninsula was, however, missed by the ARPEGE and ECMWF forecasts. The overestimation of the MSLP minimum was probably related to the difficulty of simulating a $60 \mathrm{~km}$ diameter cyclone using a model with grid spacing of about $25 \mathrm{~km}$. Most of the lowest values in MSLP minimum were reached at 0900 UTC on 26 September. After around 0900 UTC, the MSLP minimum generally increased as the low was wrongly forecasted over land.

The life cycles of the medicane from the different forecasts were analysed within the cyclone phase space following the methodology developed by Hart (2003). The cyclone phase space allows cyclones to be contrasted according to their thickness asymmetry and either cold- or warm-core structure. The cyclone phase space is based on three parameters: 900-600 hPa thermal wind $\left(-V_{\mathrm{T}}^{\mathrm{L}}\right), 600-300 \mathrm{hPa}$ thermal wind $\left(-V_{\mathrm{T}}^{\mathrm{U}}\right)$, and $900-600 \mathrm{hPa}$ storm-motion-relativethickness asymmetry $(B)$, defined as the thickness difference between right and left of current storm motion across the cyclone. With respect to the mesoscale of the low, the calculation was made here within a $200 \mathrm{~km}$ radius-a length shorter than the $500 \mathrm{~km}$ distance used originally by Hart (2003). A $500 \mathrm{~km}$ radius smooths out the warm-core structure, while it reveals the environmental asymmetry in which the mesocyclone evolved over the Strait of Sicily. As a result of the $200 \mathrm{~km}$ radius employed, near-zero values of $B$ were obtained, indicating symmetry of the medicane. Similar values (but obtained with a larger radius of $500 \mathrm{~km}$ ) were found for the case of Olga, a stereotypical example of the conversion of a non-tropical cyclone into a tropical cyclone (Hart 2003).

Figure 5 shows the $-V_{\mathrm{T}}^{\mathrm{L}}$ versus $-V_{\mathrm{T}}^{\mathrm{U}}$ diagram to distinguish between a cold-core and a warm-core structure in the lower and upper troposphere respectively. From

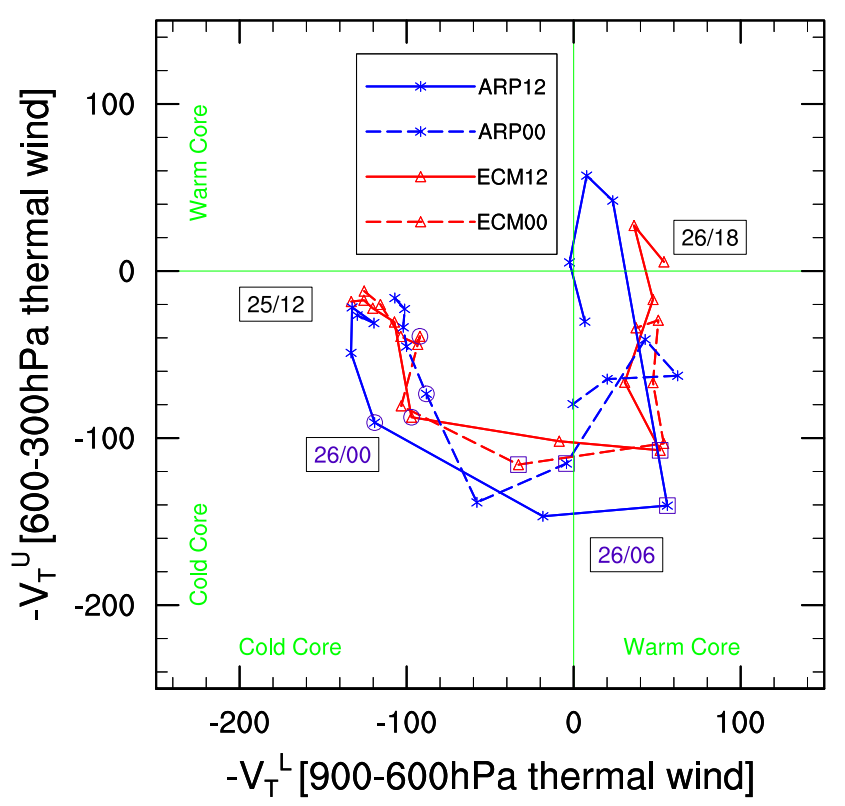

Figure 5. Cyclone phase space diagram for the ARPEGE and ECMWF forecasts starting at 0000 and 1200 UTC on 25 September 2006: $-V_{\mathrm{T}}^{\mathrm{L}}$ (scaled $900-600 \mathrm{hPa}$ thermal wind) versus $-V_{\mathrm{T}}^{\mathrm{U}}$ (scaled $600-300 \mathrm{hPa}$ thermal wind). The evolution is shown every $3 \mathrm{~h}$ from 1200 UTC on 25 September to 1800 UTC on 26 September. Points at 0000 and 0600 UTC on 26 September are indicated with open circles and squares respectively. This figure is available in colour online at wileyonlinelibrary.com/journal/qj 
1200 UTC on 25 September to about 0000 UTC on 26 September, most of the forecasts show a decrease in $-V_{\mathrm{T}}^{\mathrm{U}}$ values, the upper-level, cold core becoming stronger as the low located over the Strait of Sicily moves closer to the upperlevel trough. From 0000 to $0600 \mathrm{UTC}$ on 26 September, $-V_{\mathrm{T}}^{\mathrm{L}}$ increases from negative to positive values, indicating the development of a shallow, low-level warm core within the cyclone. The concomitant decrease in the MSLP minimum suggests that convection predicted over the Ionian Sea led to an enhancement of the low-level cyclonic circulation. From 0600 UTC on 26 September onwards, $-V_{\mathrm{T}}^{\mathrm{U}}$ increases, partly because the mesocyclone moves away from the upper-level jet. After 1200 and 1500 UTC, the low-level warm core decays in ARP00 and ECM00 respectively. In contrast, for ARP12 and ECM12 forecasts, which led to a deeper mesocyclone, the shallow, warm core built up over the Adriatic Sea. The fulltroposphere warm-core cyclone $\left(-V_{\mathrm{T}}^{\mathrm{L}}>0\right.$ and $\left.-V_{\mathrm{T}}^{\mathrm{U}}>0\right)$ was diagnosed at 0900 and 1200 UTC for ARP12 and 1500 and 1800 UTC for ECM12. Such a development of the low into a tropical-like cyclone was, however, reached in a transient way as $-V_{\mathrm{T}}^{\mathrm{U}}$ decreased to near-zero or negative values while the cyclone filled up and decayed. Note that the magnitudes of $-V_{\mathrm{T}}^{\mathrm{L}}$ and $-V_{\mathrm{T}}^{\mathrm{U}}$ achieved by the medicane are about half those analysed at the end of the tropical transition of Olga (Hart, 2003). The strongest warm core found for Olga is consistent with its largest cyclone intensity (an MSLP minimum of $973 \mathrm{hPa}$ ) as the cyclone generally increases as the warm-core strength increases.

As in Davolio et al. (2009), the ARPEGE and ECMWF forecasts starting on 25 September show strong sensitivity to the specification of the initial conditions, the forecasts starting at 1200 UTC giving a much better prediction of the mesocyclone than the forecasts starting at 0000 UTC. They all lack the strong deepening of the medicane over the Ionian Sea and its transit and maintenance as a tropical storm over the Adriatic Sea. These results support the need to simulate the mesocyclone at a higher resolution.

\section{Mesoscale forecasts}

\subsection{Numerical set-up and experimental design}

The numerical simulations at mesoscale were performed with the non-hydrostatic model Meso-NH (Lafore et al., 1998 ) version 4.7 with triply nested grids using a two-way nesting method (Stein et al., 2000). The model domains shown in Figure 6 have horizontal grid spacings of 32, 8, and $2 \mathrm{~km}$. The vertical grid had 50 levels up to $20 \mathrm{~km}$, with a spacing ranging from $60 \mathrm{~m}$ close to the surface to $600 \mathrm{~m}$ at high altitude. For the two coarser-resolution grids (32 and $8 \mathrm{~km}$ ), the subgrid-scale convection was parametrized by a mass-flux convection scheme (Bechtold et al., 2001). For the inner grid $(2 \mathrm{~km})$, explicit deep convection was permitted and the convection scheme was switched off. The microphysical scheme included all water phases with five species of precipitating and non-precipitating liquid and solid water (Pinty and Jabouille, 1998) and a modified ice to snow autoconversion parametrization following Chaboureau and Pinty (2006). Subgrid cloud cover and condensate content were parametrized as a function of the normalized saturation deficit by taking both turbulent and convective contributions into account (Chaboureau and Bechtold, 2002, 2005). The turbulence parametrization was based on a 1.5-order closure (Cuxart et al., 2000). The

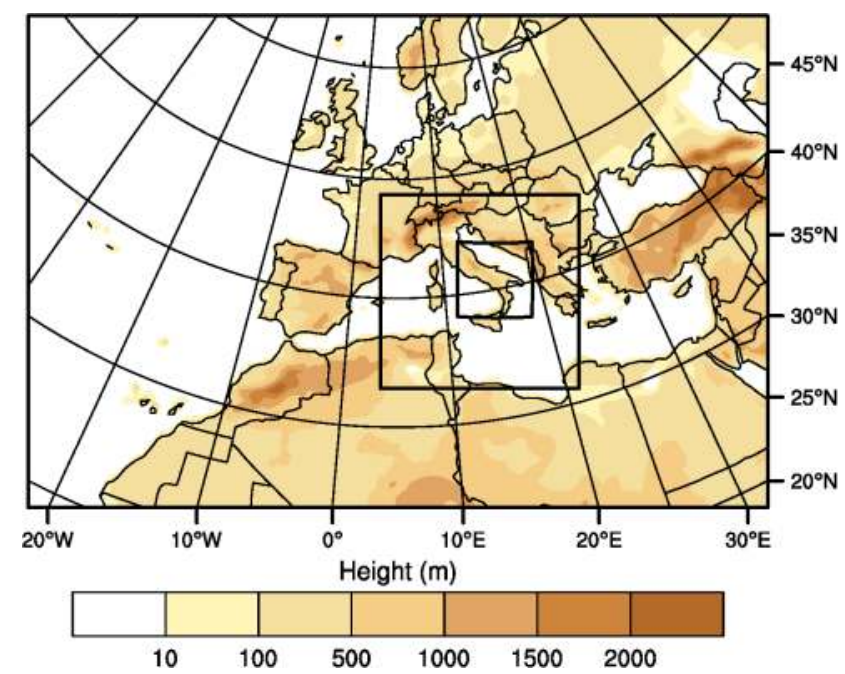

Figure 6. Topography $(\mathrm{m})$ of the $32 \mathrm{~km}$ mesh size domain used for the Meso-NH experiments. The solid black boxes indicate the location of the nested models with 8 and $2 \mathrm{~km}$ horizontal resolutions. This figure is available in colour online at wileyonlinelibrary.com/journal/qj

Table I. Characteristics of the Meso-NH experiments.

\begin{tabular}{lccc}
\hline $\begin{array}{l}\text { Initial time } \\
\text { (UTC) }\end{array}$ & $\begin{array}{c}\text { Duration } \\
(\mathrm{h})\end{array}$ & $\begin{array}{c}\text { ARPEGE } \\
\text { coupling }\end{array}$ & $\begin{array}{c}\text { ECMWF } \\
\text { coupling }\end{array}$ \\
\hline 25 Sep. 1200 & 30 & ARPA & ECMA \\
25 Sep. 0600 & 36 & ARPB & ECMB \\
25 Sep. 0000 & 42 & ARPC & ECMC \\
\hline
\end{tabular}

radiative scheme was the one used at ECMWF (Gregory et al., 2000) including the Rapid Radiative Transfer Model (RRTM) parametrization (Mlawer et al., 1997). The surface scheme was the Interactions between Soil, Biosphere and Atmosphere (ISBA) soil scheme of Noilhan and Planton (1989).

Two sets of three lagged simulations each were performed using initial and boundary conditions provided either by ARPEGE or ECMWF analyses. They were generated by shifting the initialization time of the numerical experiments. The first experiment started on 25 September at 0000 UTC, the second one at 0600 UTC and the last one at 1200 UTC. The three simulations were then integrated until 26 September at 1800 UTC. Hereafter, these two sets of simulations will be referred to as ARP and ECM experiments for the runs initialized and coupled with ARPEGE and ECMWF analyses respectively. Table I summarizes the differences characterizing the Meso-NH experiments.

\subsection{Evaluation approach and omega equation inversion}

The quality of the simulations in terms of cloud and precipitation was assessed through the off-line comparison of synthetic brightness temperatures (BT) against observations (see Chaboureau et al., 2008, and references therein). Two types of observations and wavelengths were considered: first the MSG channels at $10.8 \mu \mathrm{m}$ (infrared window channel) and $6.2 \mu \mathrm{m}$ (upper tropospheric water vapour channel); second, AMSU-B microwave channels 3-5, which detect convective areas. The MSG BT at $10.8 \mu \mathrm{m}$ was used 
(a) $\omega$ model at $400 \mathrm{hPa}$

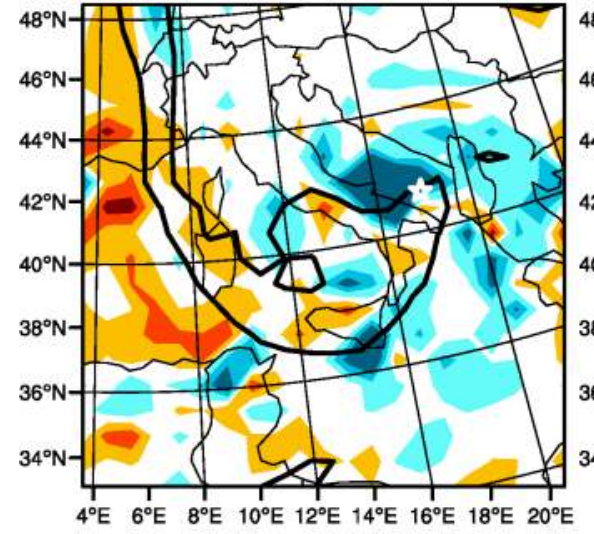

(b) $\omega \mathrm{AB}$ at $400 \mathrm{hPa}$

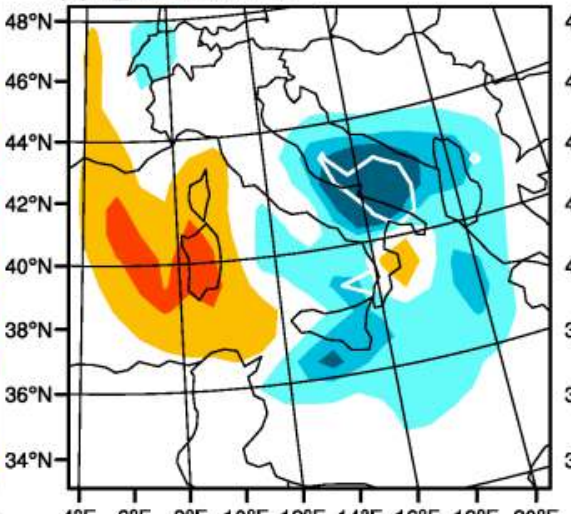

(c) $\omega$ dyn at $400 \mathrm{hPa}$

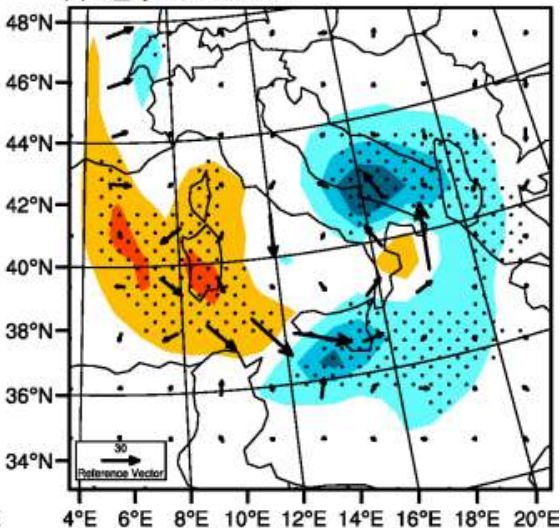

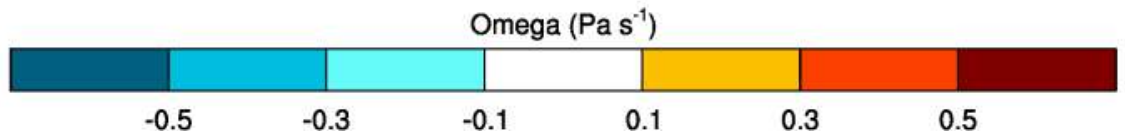

Figure 7. Vertical motions (shaded, $\mathrm{Pa} \mathrm{s}^{-1}$ ) at $400 \mathrm{hPa}$ for ECMA at $1200 \mathrm{UTC}$ on 26 September 2006. (a) $\omega_{\text {model }}$ and $300 \mathrm{hPa}$ PV at $1.5 \mathrm{PVU}$ (thick line) (b) $\omega_{\mathrm{AB}}$ and diabatic heating at $1 \mathrm{~K} \mathrm{~h}^{-1}$ (white line), (c) $\omega_{\mathrm{dyn}}$, Q vector and contribution of $\omega_{\mathrm{dyn}}$ to $\omega_{\mathrm{AB}}$ when $\left|\omega_{\mathrm{AB}}\right|>0.1$ Pa s${ }^{-1}$ (dotted when contribution is larger than 50\%). In (a), the star gives the position of the medicane. This figure is available in colour online at wileyonlinelibrary.com/journal/qj

to characterize cloud cover as it is mainly affected by cloudtop heights, with values less than $230 \mathrm{~K}$ corresponding to high-level opaque clouds (e.g. Söhne et al., 2008), and values less than $260 \mathrm{~K}$ associated with high- and mid-level clouds. The MSG BT at $6.2 \mu \mathrm{m}$ is sensitive to upper-tropospheric humidity, high BTs being associated with dry intrusion of stratospheric origin in a baroclinic region (Argence et al., 2009). Following Funatsu et al. (2007), we used the observations from AMSU-B moisture channels (3-5) to detect the presence of hydrometeors through the scattering of radiation, which lowered the BT compared to its surroundings. Funatsu et al. (2007) showed that a value of channels 3 minus 5 (hereafter, B $3 \mathrm{~m} 5$ ) of more than $-8 \mathrm{~K}$ corresponded statistically to moderate rainfall (about $10 \mathrm{~mm}$ in $3 \mathrm{~h}$ ). Furthermore, using a deep convection threshold (DCT), they detected deep convection over the Mediterranean. DCT was defined such that $\mathrm{B} 3 \mathrm{~m} 5, \mathrm{~B} 4 \mathrm{~m} 5$ and $\mathrm{B} 3 \mathrm{~m} 4$ (i.e. AMSU-B channels 3 minus 5, 4 minus 5, and 3 minus 4 respectively) were simultaneously equal to or larger than zero. DCT was found to correspond to heavy rainfall (about $20 \mathrm{~mm}$ in $3 \mathrm{~h}$ ).

The forcing due to the upper-level jet was estimated by inverting the omega equation. As in Mallet et al. (1999), we used the Davies-Jones (1991) Alternative Balance (AB) omega equation, which is based upon a nonlinear balance that is more accurate than the often used quasi-geostrophic balance. It allows the baroclinic and diabatic contributions to the vertical motion to be diagnosed. We obtained a twoterm decomposition of $\omega_{\mathrm{AB}}$, the vertical motion deduced from the $\mathrm{AB}$ omega equation: $\omega_{\text {dyn }}$ associated with the Q-vector divergence and $\omega_{\text {diab }}$ the diabatic contribution, mainly due to the latent-heat release in the free troposphere. The calculation was made after averaging model outputs on a grid of $64 \mathrm{~km}$ mesh. An example is shown for ECMA at 1200 UTC on 26 September 2006 (Figure 7). At that time, the upper-level trough as shown with the 1.5 PVU line at $300 \mathrm{hPa}$ rolled cyclonically around the medicane located over the Adriatic Sea (Figure 7(a)). Downward motion at $400 \mathrm{hPa}$ occurred mostly in the vicinity of Corsica and Sardinia, while upward motions were found ahead of the trough over the Adriatic and Ionian Seas and also over the southern part of the Tyrrhenian Sea. The vertical motion

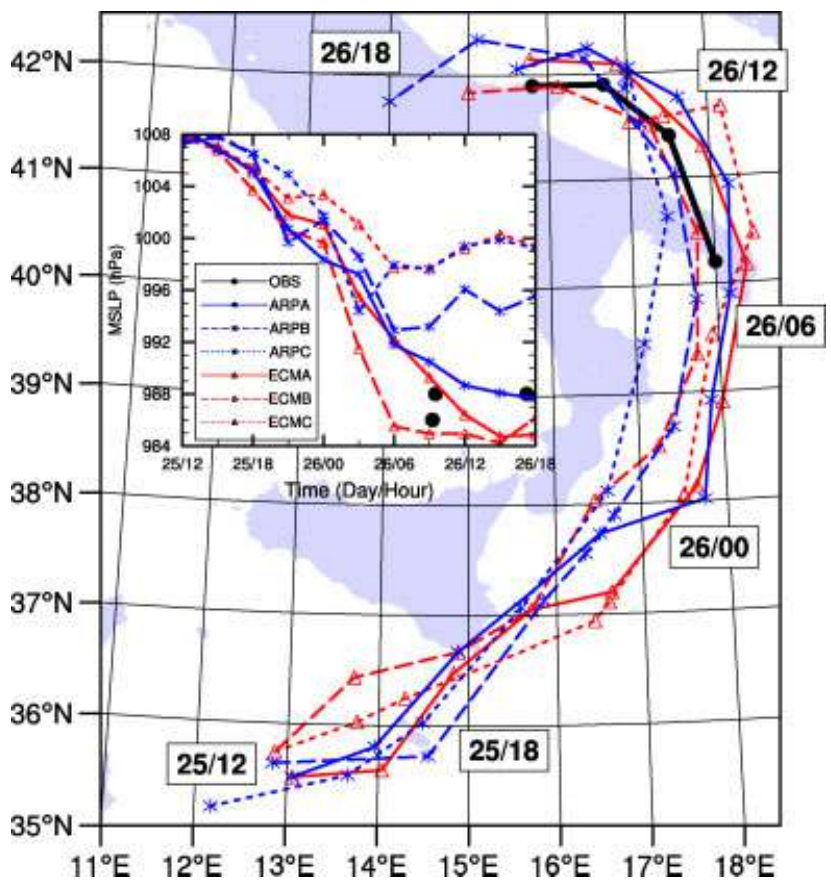

Figure 8. As Figure 4 but for the ARP (asterisks) and ECM (triangles) Meso-NH forecasts. This figure is available in colour online at wileyonlinelibrary.com/journal/qj

obtained by the inversion of the omega equation $\omega_{\mathrm{AB}}$ shows similar patterns, albeit smoother in magnitude (Figure $7(\mathrm{~b})$ ). Diabatic heating larger than $1 \mathrm{~K} \mathrm{~h}^{-1}$ at $400 \mathrm{hPa}$ occurred over the Tyrrhenian and Adriatic Seas. While diabatic forcing contributed the most to vertical motions over the Tyrrhenian Sea, the dynamical forcing was the main contributor to upward motions over the Adriatic Sea (Figure 7(c)).

\subsection{Overview}

An overview of the Meso-NH forecasts is given by the tracks of the resulting Mediterranean cyclone (Figure 8). As for the global model forecasts, Meso-NH forecasts show tracks that are similar to each other within $1^{\circ}$ of longitude and latitude. 
But they contrast with their global model counterparts as the Meso-NH tracks, and particularly ARPA, ECMA and ECMB, almost overlay the analysed track of the medicane over the Adriatic Sea with averaged errors of 34, 18, and $74 \mathrm{~km}$, respectively.

In general, the Meso-NH forecasts showed a sharp decrease in MSLP from about 1800 UTC on 25 September to 0600 UTC on 26 September. They deviated from the global model forecasts, for which the deepening was delayed by further $6 \mathrm{~h}$. Afterwards, the Meso-NH forecasts differed significantly from one another in terms of MSLP minimum. ARPB, ARPC and ECMC had moderate MSLP values, down to 993,994 and $998 \mathrm{hPa}$ respectively, then increasing MSLP values from 0900 UTC on 26 September onwards. ARPA, ECMA and ECMB produced a deeper low, reaching $988 \mathrm{hPa}$ or lower and, later in the day, at 1500 or 1800 UTC on 26 September. Only ECMA and ECMB gave the MSLP minimum of $986 \mathrm{hPa}$ recorded at $0900 \mathrm{UTC}$ on 26 September at Nardò, on the southwestern side of Salento (Moscatello et al., 2008b). For these three successful forecasts, the MSLP fell by more than $18 \mathrm{hPa}$ in $24 \mathrm{~h}$. This value equals 1 Bergeron $=24$ (hPa per day) $\sin (\phi) / \sin \left(60^{\circ}\right)$ with $\phi$ the latitude of the storm centre, taken here at $40^{\circ}$. The $\sin (\phi) / \sin \left(60^{\circ}\right)$ factor was introduced by Sanders and Gyakum (1980) to geostrophically adjust Bergeron's original characterization of 24 (hPa per day) for latitudes other than that of Bergen $\left(60^{\circ} \mathrm{N}\right)$. According to this criterion, the storm can be classified as an explosively intensifying cyclone or 'bomb'. Note also that, in ARPA, ECMA and ECMB, sustained $10 \mathrm{~m}$ wind speeds reached $25 \mathrm{~m} \mathrm{~s}^{-1}$ on the morning of 26 September, i.e. in the intensity range of $17-32 \mathrm{~m} \mathrm{~s}^{-1}$, which classifies the medicane as a tropical storm.

As for the global models, the life cycle of the mesoscale cyclone forecasted by Meso-NH was analysed in the cyclone phase space, using a $200 \mathrm{~km}$ radius for the calculation. As also seen for the operational forecasts, the resulting $B$ parameter took near-zero values, indicating symmetry in the low-leve thickness of the cyclone. The $-V_{\mathrm{T}}^{\mathrm{L}}$ versus $-V_{\mathrm{T}}^{\mathrm{U}}$ diagram is shown in Figure 9. From 1200 UTC on 25 September to about 0000 UTC on 26 September, most of the forecasts show a decrease in $-V_{\mathrm{T}}^{\mathrm{U}}$. Like that of the global models, the mesoscale cyclone forecasted by Meso- $\mathrm{NH}$ was associated with a developing shallow, upper-level, cold core while coming closer to the upper-level trough. In the morning of 26 September, $-V_{\mathrm{T}}^{\mathrm{L}}$ increased. In ECMC, this eventually led to the decay of the low-level cyclone. At around 0600 UTC, every forecast except ECMC showed a low-level, warm core. In ARPB and ARPC, the shallow, warm core dissipated in the next $3 \mathrm{~h}$ or so. In ARPA, ECMA and ECMB, the shallow, warm core developed further over the Ionian Sea as $-V_{\mathrm{T}}^{\mathrm{L}}$ still increased. From about $0900 \mathrm{UTC},-V_{\mathrm{T}}^{\mathrm{U}}$ increased for all the simulations, partly because the mesocyclone moved away from the upper-level jet. In ARPA, ECMA and ECMB, $-V_{\mathrm{T}}^{\mathrm{U}}$ finally reached positive values around 1500 UTC. At this final stage, ARPA, ECMA and ECMB showed a structure characteristic of a tropical cyclone, $-V_{\mathrm{T}}^{\mathrm{L}}$ and $-V_{\mathrm{T}}^{\mathrm{U}}$ being positive, with $-V_{\mathrm{T}}^{\mathrm{L}}$ having the greater magnitude.

The development of a full-tropospheric warm core requires the development and maintenance of convection near the cyclone core. This was achieved more clearly for the successful Meso-NH forecasts than for their ARPEGE and ECMWF counterparts. Furthermore, the development of the mesocyclone from an extratropical cyclone to a subtropical cyclone and finally to a tropical storm is an illustrative

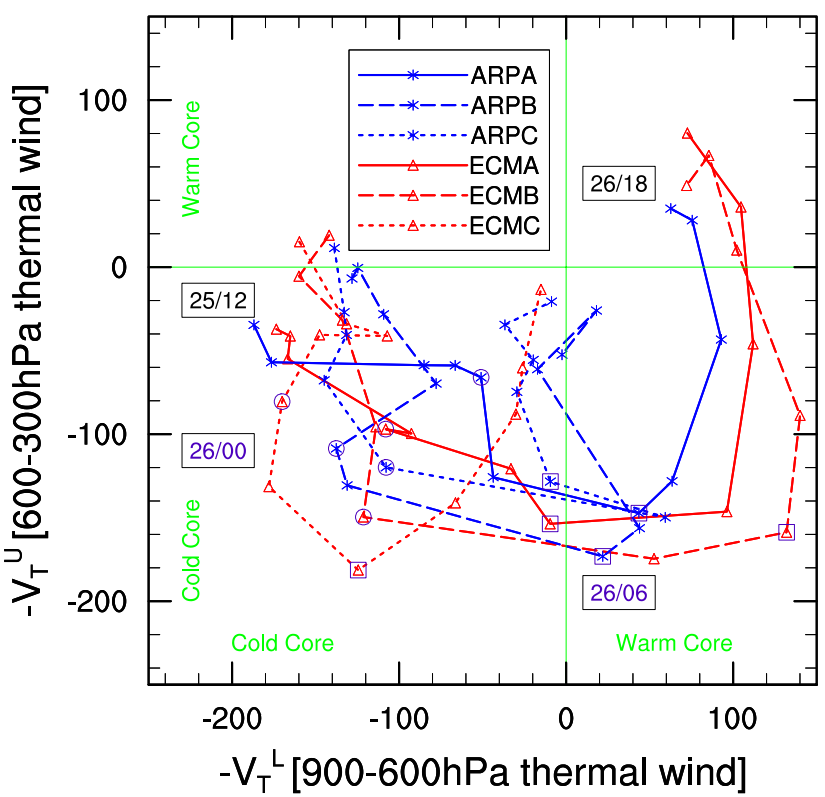

Figure 9. As Figure 5 but for the ARP (asterisks) and ECM (triangles) Meso-NH forecasts. This figure is available in colour online at wileyonlinelibrary.com/journal/qj

example of tropical transition (Davis and Bosart, 2004). However, it is worth noting that, according to the diagnostic made in the cyclone phase space, the characteristics of a tropical cyclone were achieved by the medicane at 1500 and 1800 UTC only. This transient property contrasts with the long life of tropical cyclones.

\subsection{Explosive growth of the medicane}

The explosive development of the medicane is now examined based on the most successful forecasts: ECMA. Prior to the triggering of convection starting at 2100 UTC on 25 September, the mesocyclone developed a positive lowlevel PV anomaly as it moved along the cold front (Figure 10). At 1200 UTC, a low-level PV was located south of the cold front, in the warm sector characterized by convective available potential energy (CAPE) greater than $3000 \mathrm{~J} \mathrm{~kg}^{-1}$ and reduced static stability at $450 \mathrm{hPa}$, just underneath the southern tip of the upper-level trough.

At 1500 UTC, a positive anomaly is still associated with the shallow mesocyclone (Figure 10(e)). The transverse wind was increased at low levels, allowing PV advection along the sloping isentropes, while cross-wind can transport warm, moist air at low levels. This configuration is reminiscent of an environment favourable to the development of a Rossby diabatic wave (e.g. Mallet et al., 1999; Wernli et al., 2002). However, the upward motion was too small (less than $0.02 \mathrm{~m} \mathrm{~s}^{-1}$ ) and, even though diabatic heating over $0.5 \mathrm{~K}$ per day occurred along the cold front, it was too far away from the mesocyclone to enhance its associated positive PV anomaly.

Instead, the PV at low level was mainly formed because of orographic forcing as shown at 1800 UTC (Figure 10(c)). Cross-wind stronger than $8 \mathrm{~m} \mathrm{~s}^{-1}$ was present at less than $50 \mathrm{~km}$ from the mesocyclone centre. The southeasterly warm, moist air was blocked by Sicily, which resulted in strong upward motion leading to cloud diabatic heating. In terms of PV, latent heat release is primarily associated with production of PV at low levels and destruction of PV above 

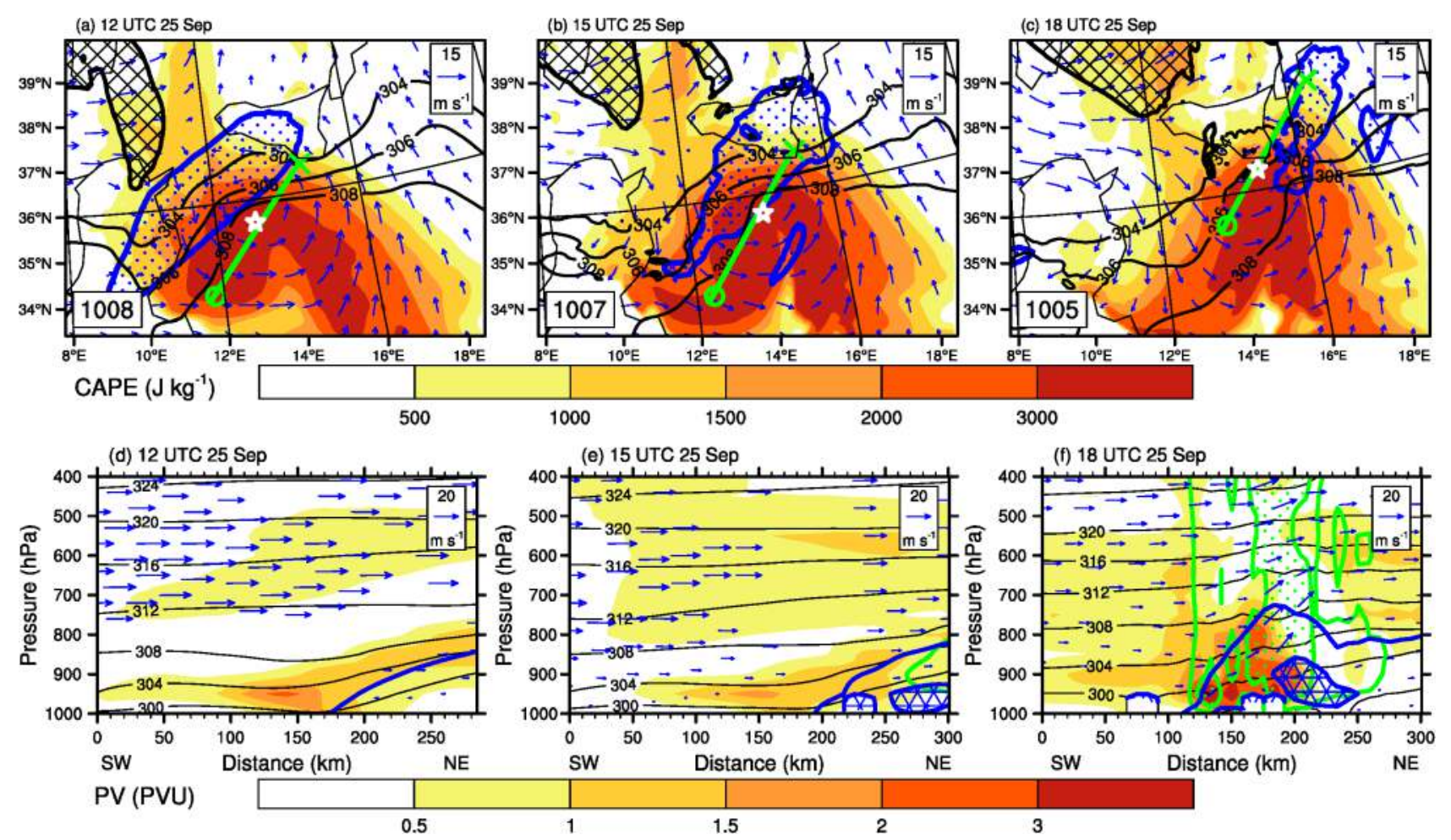

Figure 10. Results for ECMA at 1200, 1500 and 1800 UTC (left to right) on 25 September 2006. Top: CAPE (shaded, $\mathrm{Jg}^{-1}$ ), potential vorticity at $300 \mathrm{hPa}$ (hatched when larger than $2 \mathrm{PVU}$ ), static stability at $450 \mathrm{hPa}$ (dotted when lower than $0.610^{-4} \mathrm{~s}^{-2}$ ), wind at $850 \mathrm{hPa}$ (vectors, m s $\mathrm{s}^{-1}$ ) and potential temperature at $850 \mathrm{hPa}$ (thin lines, contours for 304, 306 and $308 \mathrm{~K}$ ). The star and the figure in the white box give the position and MSLP minimum, respectively, of the mesocyclone. Bottom: vertical cross-section of potential vorticity (shaded, PVU), tangent wind (vector, the vertical component has been multiplied by a factor of 20, only shown when the vertical wind speed is greater than $0.02 \mathrm{~m} \mathrm{~s}^{-1}$ ), cross-wind speed (thick lines, contours for 0 and $8 \mathrm{~m} \mathrm{~s}^{-1}$, hatched when larger than $8 \mathrm{~m} \mathrm{~s}^{-1}$ ), potential temperature (thin lines, every $4 \mathrm{~K}$ ) and diabatic heating greater than 0.5 and $5 \mathrm{~K}$ per day (dotted when greater than $5 \mathrm{~K}$ per day along the lines shown on the top panels. This figure is available in colour online at wileyonlinelibrary.com/journal/qj

the level of maximum diabatic heating. In consequence, a PV anomaly larger than 2 PVU was formed between 950 and $800 \mathrm{hPa}$ in an area where CAPE was consumed and the upper tropospheric static stability was enhanced. As the mesocyclone moved along the southern tip of Sicily in every simulation (Figure 8), the enhancement of the positive PV anomaly can be attributed to the additional orographic forcing that occurred for all the simulations. But the resulting PV anomaly was of contrasting magnitude among the different simulations, which changed the subsequent development of convection associated with the medicane.

From 2100 UTC on 25 September onwards, the medicane began to deepen as deep convection was triggered. Details of the time evolution of the convective activity during the intensification stage of the medicane over the Ionian Sea and its transit over the Adriatic Sea at 2100 UTC on 25 September and 0400 and 1200 UTC on 26 September are shown for the observations and ECMA in Figure 11. These times were chosen as the closest to those of AMSU observations (2110, 0433 and 1128 UTC). Throughout this time sequence, deep convection as shown by DCT and very low MSG $10.8 \mu \mathrm{m} \mathrm{BT}$ values (e.g. less than $230 \mathrm{~K}$ ) were observed over Apulia as well as in the vicinity of the medicane.

At 2100 UTC on 25 September, convection was found along the downstream flank of the upper-level trough (shown with high values of BT at $6.2 \mu \mathrm{m}$ ) i.e. along the western Italian coast and at the eastern tip of the trough, which was over the Ionian Sea. While its predicted convection was less ubiquitous over mainland Italy than observed, ECMA forecasted deep convection over the Ionian Sea correctly. In particular, the circular structure associated with the mesocyclone was reproduced well. The MSLP minimum was $1002 \mathrm{hPa}$.

At 0400 UTC on 26 September, both DCT and MSG $10.8 \mu \mathrm{m} \mathrm{BT}<230 \mathrm{~K}$ indicated two areas of convection: one organized in a line over Apulia and the Adriatic Sea and the other with a circular pattern over the Ionian Sea, a signature of the medicane. They were still along the downstream flank of the upper-level trough. In ECMA, the most active cell was located over the Ionian Sea and showed a circular pattern close to what was observed in $10.8 \mu \mathrm{m} \mathrm{BT}$, but with a DCT underestimation. The depth of the low decreased dramatically, by $9 \mathrm{hPa}$ in $6 \mathrm{~h}$, to reach $992 \mathrm{hPa}$ at 0600 UTC.

At 1200 UTC, the MSG $10.8 \mu \mathrm{m}$ BT field was organized in a cyclonic structure with the lowest values $(<230 \mathrm{~K})$ spanning the Adriatic Sea and its neighbourhood. Inside this area, B3m5 $>-8 \mathrm{~K}$ spread around the Gargano promontory, while DCT persisted in a narrow sector, mainly over land. Almost the only DCT over sea was associated with the medicane, located at $41.4^{\circ} \mathrm{N}, 17.5^{\circ} \mathrm{E}$ according to Moscatello et al. (2008b). The region of high $6.2 \mu \mathrm{m}$ BT values was stretched to form a dry slot that encircled the south and east of the medicane. The hook observed over the Adriatic Sea in the infrared window and water vapour MSG images suggests an interaction of the upper-level circulation with the surface cyclone. A similar cyclonic pattern was found for the MSG BTs at $10.8 \mu \mathrm{m}$ and $6.2 \mu \mathrm{m}$ from ECMA. MSG $10.8 \mu \mathrm{m}$ BTs were, however, greater than observed. The convective activity, albeit too low, was concentrated to the south of the MSLP minimum, located at $41.3^{\circ} \mathrm{N}, 17.9^{\circ} \mathrm{E}$, with a value of $986 \mathrm{hPa}$. 

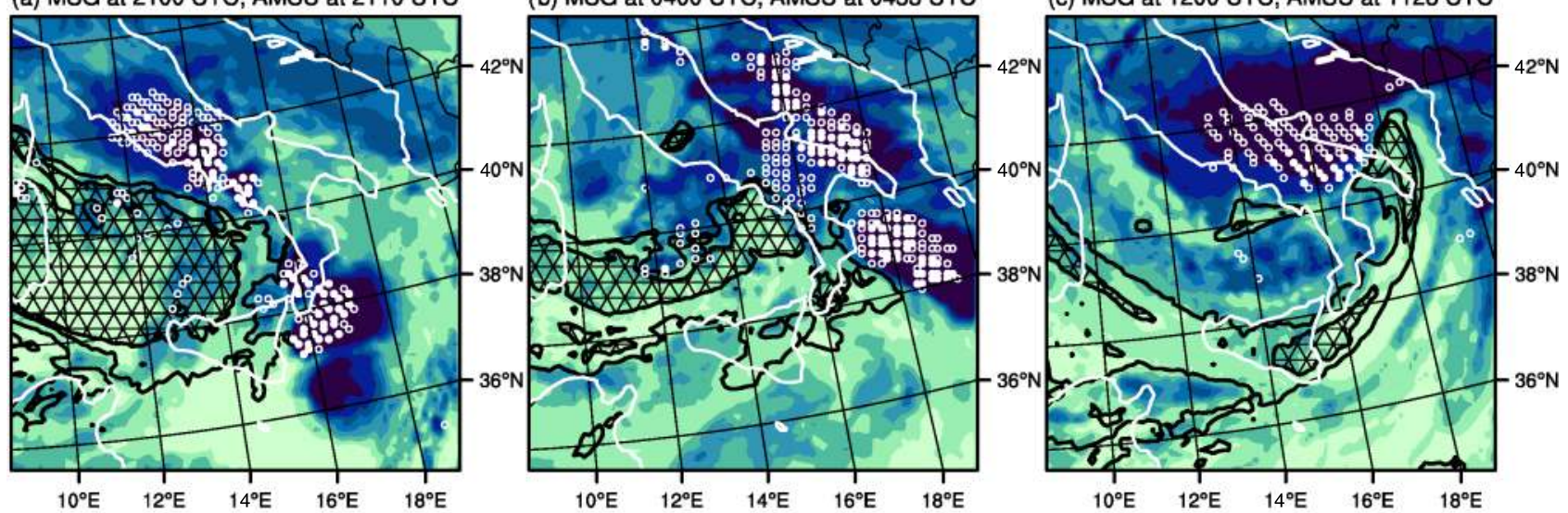

(d) ECMA at 2100 UTC

(e) ECMA at 0400 UTC

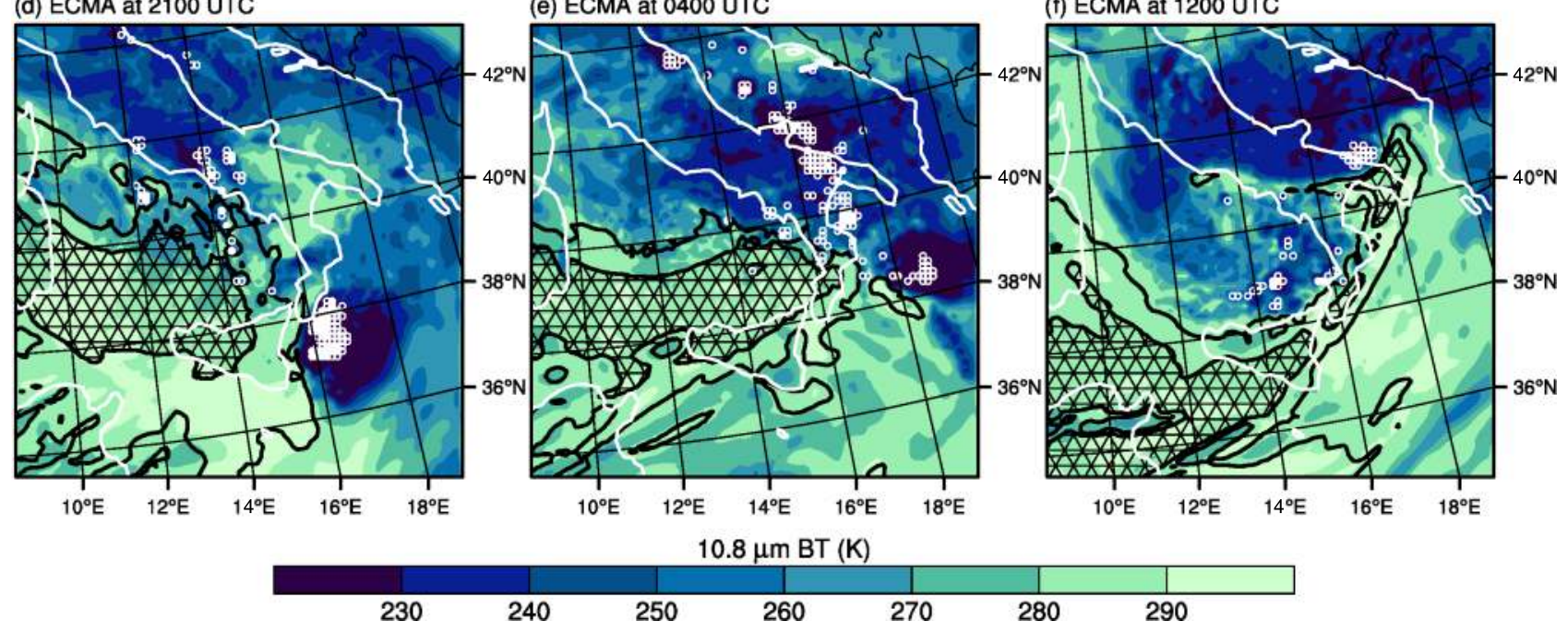

Figure 11. Satellite diagnostics at (left) 2100 UTC on 25 September 2006, (centre) 0400 UTC, and (right) 1200 UTC on 26 September $2006: 10.8$ um BT (K, shading), $6.2 \mu \mathrm{m} \mathrm{BT} \mathrm{(thick} \mathrm{lines,} \mathrm{contours} \mathrm{at} 236$ and $238 \mathrm{~K}$, hatched when larger than $238 \mathrm{~K}$ ), B3m5 > $-8 \mathrm{~K}$ (open circles) and DCT (filled circles) (values defined in the text) obtained from (top) MSG and NOAA observations, and (bottom) ECMA forecasts. This figure is available in colour online at wileyonlinelibrary.com/journal/qj

The interaction of the vertically developed PV tower with the upper-level jet leading to the rapid development of the medicane is highlighted on 26 September for ECMA with a time series of horizontal and vertical sections across the medicane (Figure 12). At 0000 UTC, the low penetrated over the Ionian Sea with an MSLP minimum of $1001 \mathrm{hPa}$. Located below the core of the upper-level jet on its anticyclonic shear side, the low-level PV tower was limited to the $700 \mathrm{hPa}$ height in the vertical direction (also seen with the isentropes) and wind speeds higher than $20 \mathrm{~m} \mathrm{~s}^{-1}$ were limited to a $20 \mathrm{~km}$ wide core in the first $100 \mathrm{hPa}$ of the atmosphere. Upward dynamical forcing shown with $\omega_{\text {dyn }}$ less than $-0.4 \mathrm{~Pa} \mathrm{~s}^{-1}$ was located at the eastern tip of the upper-level trough. The transverse indirect ageostrophic circulation led to southerly upper-level winds and upward motions on the left jet-exit region characterized by steep isentropic surfaces. Afterwards, the low came closer to the axis of the upper-level jet $\left(-V_{\mathrm{T}}^{\mathrm{U}}\right.$ decreased and the low's magnitude increased by $50 \%$ ); it developed a low-level warm core $\left(-V_{\mathrm{T}}^{\mathrm{L}}\right.$ increased $)$ and the $\mathrm{PV}$ tower reached a height of $600 \mathrm{hPa}$.

At 0600 UTC, the low moved below the left jet-exit region. It deepened to $992 \mathrm{hPa}$, while wind speeds higher than $20 \mathrm{~m} \mathrm{~s}^{-1}$ spread over a core $60 \mathrm{~km}$ wide $\left(-V_{\mathrm{T}}^{\mathrm{L}}\right.$ became positive). The low also developed vertically to the $300 \mathrm{hPa}$ level, allowing the positive PV anomaly in the lower troposphere to interact with the PV reservoir at $250 \mathrm{hPa}$.
As a consequence of upward forcing induced by the jet, the upward motion was enhanced. In the next $6 \mathrm{~h}$, the low-level, warm core developed as $-V_{\mathrm{T}}^{\mathrm{L}}$ was still increasing and moved away from the core of the upper-level jet ( $-V_{\mathrm{T}}^{\mathrm{U}}$ increased).

At 1200 UTC, the medicane was over the Adriatic Sea. It further deepened to an MSLP minimum of $986 \mathrm{hPa}$ as the low moved northward away from the upper-level jet. A large contribution to the upward motion was still due to dynamical forcing. A vertically aligned tower of positive PV and temperature anomalies was formed, while the intensity of the upper-level jet decreased. The low was characterized by a $40 \mathrm{~km}$ core of wind speed over $30 \mathrm{~m} \mathrm{~s}^{-1}$ from the surface up to $500 \mathrm{hPa}\left(-V_{\mathrm{T}}^{\mathrm{L}}\right.$ reached its maximum value). In the next $6 \mathrm{~h}$, the medicane was transported within the southeasterly flow and landed over the Gargano promontory.

\subsection{Sensitivity to pseudo initial conditions}

The difference in scenario between the Meso-NH forecasts is now examined in order to verify the mechanisms put forward in the previous section. At 1200 UTC on 25 September, all the forecasts show an area of low static stability at $450 \mathrm{hPa}$ across the Strait of Sicily overlapping a region of positive convective available potential energy (not shown). They differ slightly, however, on the reduction in static stability 
(a) 00 UTC 26 Sep

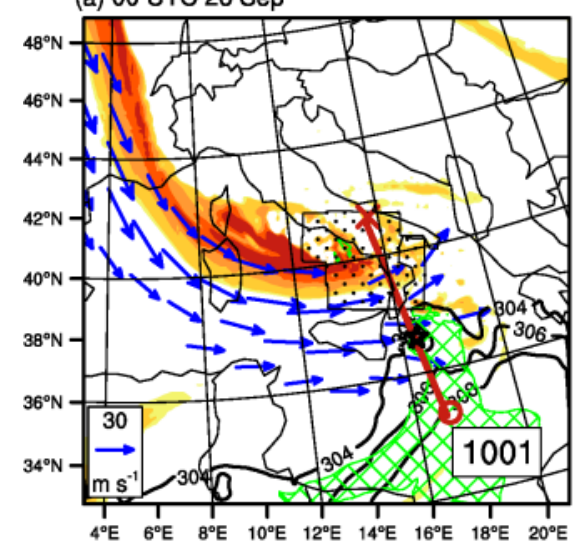

(d) 00 UTC 26 Sep

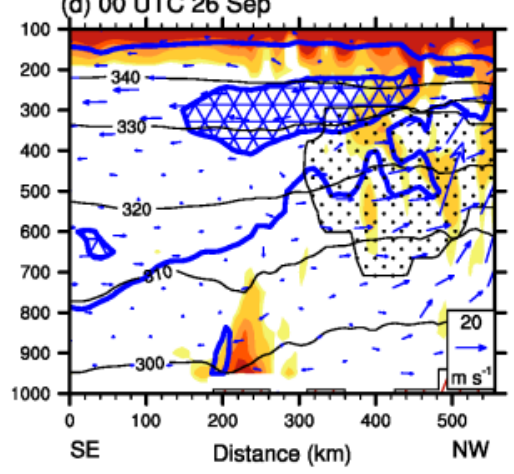

(b) 06 UTC 26 Sep

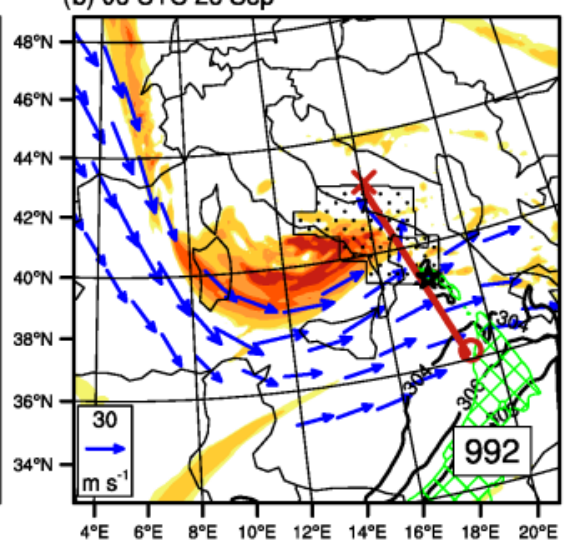

(c) 12 UTC $26 \mathrm{Sep}$

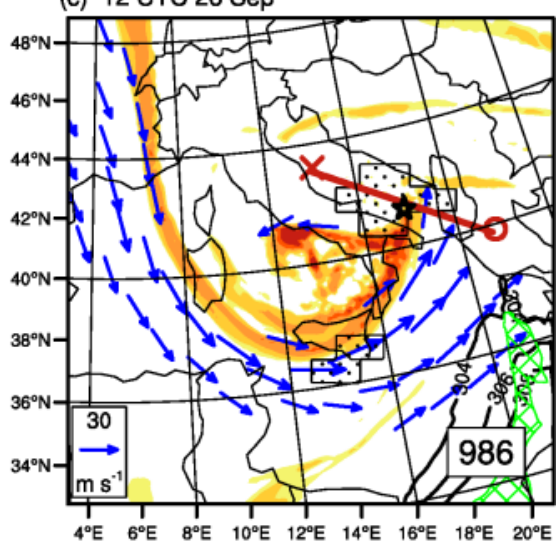

(e) 06 UTC 26 Sep

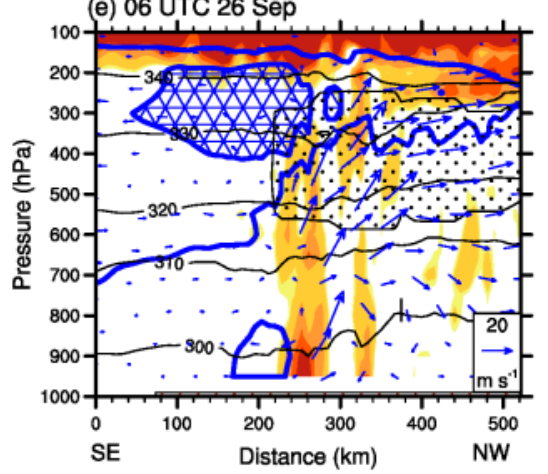

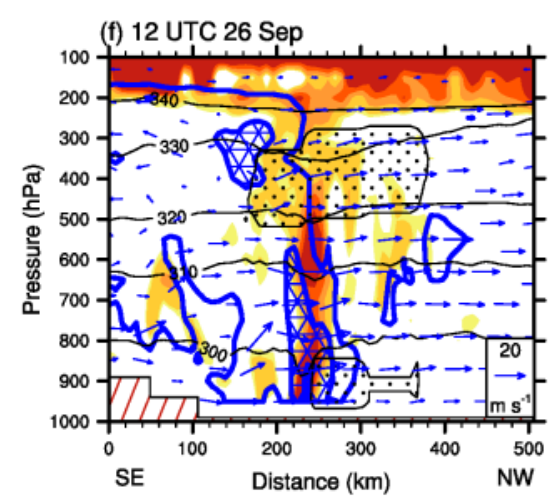

Potential Vorticity (PVU)

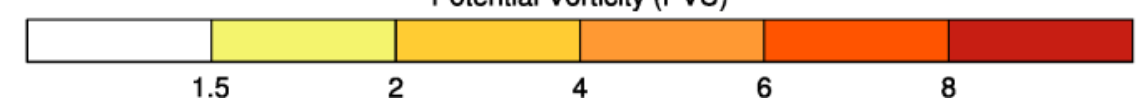

Figure 12. Results for ECMA at 0000, 0600, and 1200 UTC on 26 September 2006. Top: potential vorticity at 300 hPa (shaded, PVU), wind speed at $300 \mathrm{hPa}$ over $30 \mathrm{~m} \mathrm{~s}^{-1}$ (vector), $\omega_{\text {dyn }}$ at $400 \mathrm{hPa}$ less than $-0.4 \mathrm{~Pa} \mathrm{~s}^{-1}$ (dotted) and CAPE larger than $1500 \mathrm{~J} \mathrm{~kg}^{-1}$ (hatched). The star and the figure in the white box give the position and MSLP minimum, respectively, of the mesocyclone. Bottom: vertical cross-section of potential vorticity (shaded, PVU), wind speed at 20 and $30 \mathrm{~m} \mathrm{~s}^{-1}$ (thick lines, hatched when larger than $30 \mathrm{~m} \mathrm{~s}^{-1}$ ), tangent wind (vector, with vertical component multiplied by a factor of 20), potential temperature (thin lines, every $10 \mathrm{~K}$ ) and $\omega_{\text {dyn }}$ less than $-0.4 \mathrm{~Pa} \mathrm{~s}^{-1}$ (dots) along the lines shown on the top figures. This figure is available in colour online at wileyonlinelibrary.com/journal/qj

across the Strait of Sicily and the spatial extent of the positive CAPE area, with larger CAPE values for ARPA and ECMA.

Because of differences in pseudo initial conditions, the convective activity associated with the mesocyclone was contrasted between the simulations as shown using a time-radius diagram of satellite diagnostics within a $40 \mathrm{~km}$ circle centred on the mesocyclone (Figure 13). AMSU observations were taken as the closest to each 3-hourly time. They were missing at 1200 UTC 25 September and 0300 and 0900 UTC 26 September. Using the DCT diagnostics, deep convection was observed to be triggered in the vicinity of the mesocyclone at 2100 UTC. Deep convection then decreased at 0000 UTC on 26 September to further reintensify over the Ionian Sea in the morning. The convective activity was finally strongly reduced from 1200 UTC onwards. The temporal evolution observed by DCT was reproduced in most of the simulations, but with notable differences in magnitude. In particular, ARPC and ECMC did not produce any DCT at times when DCT was observed and predicted by the other simulations. However, the time lag and missing data in AMSU observations and difficulties in accurately representing the radiative properties of snow in the microwave region (Meirold-Mautner et al., 2007) make the comparison a little uncertain.

In contrast to AMSU observations, MSG provided measurements at the right time, which allowed a much fairer comparison with the Meso-NH forecasts (Figure 13(b)). Here, the threshold of BT less than $250 \mathrm{~K}$ was chosen to diagnose deep, high clouds (as in Argence et al., 2009). A first peak in number of deep, high clouds occurred at 1800 UTC on 25 September. This corresponds to the development of clouds forced by the orography of Sicily (see Figure 10). As the medicane intensified over the Ionian Sea, the number of deep, high clouds steadily increased to a second peak at 0900 UTC on 26 September. This increase was correctly reproduced by ARPA and, to a less extent, by ECMA and ECMB. In contrast, ARPB and ECMC produced fewer deep, high clouds over the Ionian Sea, while the number of deep, high clouds decreased too early in ARPC.

The rather realistic forecasts provided by ARPA, ECMA and ECMB with respect to satellite images confirm the success obtained for these simulations in terms of track, MLSP minimum and precipitation. A much larger disagreement was found when looking at other forecasts. For example, clear sky was wrongly forecasted by ECMC over the Ionian Sea north of $38^{\circ} \mathrm{N}$ at 0000 UTC on 26 September. The cloud assessment is summarized with a statistical evaluation of cloud cover forecasts based on MSG observations at $10.8 \mu \mathrm{m}$. The Equitable Skill Score (ETS) for BT less than $250 \mathrm{~K}$ is shown in Figure 14. ETS quantifies the ability of the model to forecast deep, high clouds at the right location. It was calculated over the inner domain. ETS values ranged 

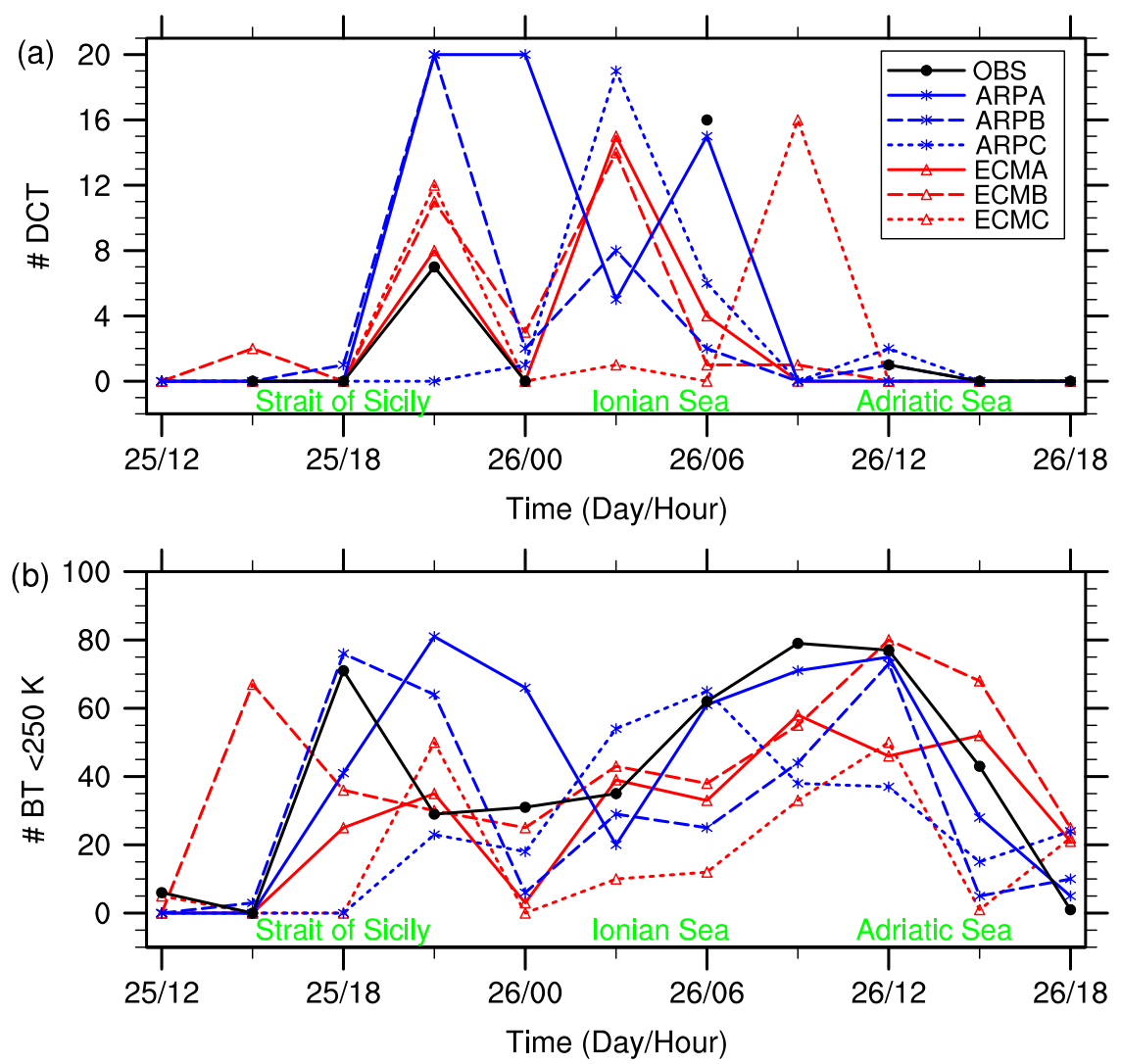

Figure 13. Time evolution of number of (a) DCT and (b) $10.8 \mu \mathrm{m}$ BT less than $225 \mathrm{~K}$ within a circle of $40 \mathrm{~km}$ radius centred in the medicane. This figure is available in colour online at wileyonlinelibrary.com/journal/qj

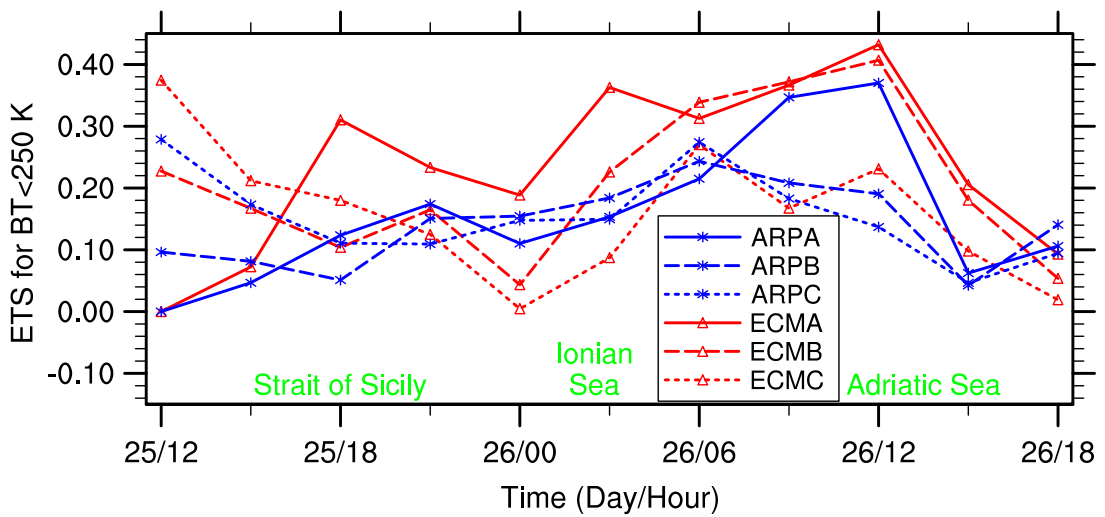

Figure 14. Comparison between MSG observations and the Meso-NH forecasts for the $10.8 \mu \mathrm{m}$ channel every 3 h: equitable skill score (ETS) for the $250 \mathrm{~K}$ threshold. The location of the mesocyclone is given by the sea names. This figure is available in colour online at wileyonlinelibrary.com/journal/qj

between 0 and 0.45 , with the lowest values obtained on the afternoon of 25 September when the low was over the Strait of Sicily. In contrast, the highest values were obtained on the morning of 26 September, when the low was over the Ionian Sea. Consistently with the results obtained on the track, MSLP minimum and precipitation, ARPA, ECMA and ECMB represented the cloud cover more successfully than the other forecasts most of the time, at least from 0900 UTC on 26 September onwards. This gives some confidence in the realism of the cloud diabatic processes associated with the medicane and simulated by the most successful forecasts.

The difference in pseudo initial conditions led to changes in the interaction between low and upper levels. The vertical structure of PV is examined in Figure 15 using a time-pressure diagram of PV averaged within a $40 \mathrm{~km}$ circle centred on the mesocyclone. In addition, the transit of the mesocyclone below the upper-level jet and the upper-level dynamical forcing are shown by using the mean value of the horizontal wind speed and $\omega_{\text {dyn }}$ respectively.

On the afternoon of 25 September, the low was over the Strait of Sicily on the anticyclonic shear side of the jet. Around 1800 UTC and afterwards, a shallow PV tower appeared, resulting in the deepening of the low for all the forecasts. At 2100 UTC, the three successful forecasts (ARPA, ECMA and ECMB) were among the most convectively active (see Figure 13(a)), while the least active forecast was ARPC, for which the deepening was the least pronounced. At 0000 UTC on 26 September, the mesocyclone began to move below the upper-level jet over the Ionian Sea. Around 0300 UTC, ARPA, ECMA and ECMB show a PV tower taller than $250 \mathrm{hPa}$. At that time, the second peak in convective activity came as the low moved below the 
(a) ARPA

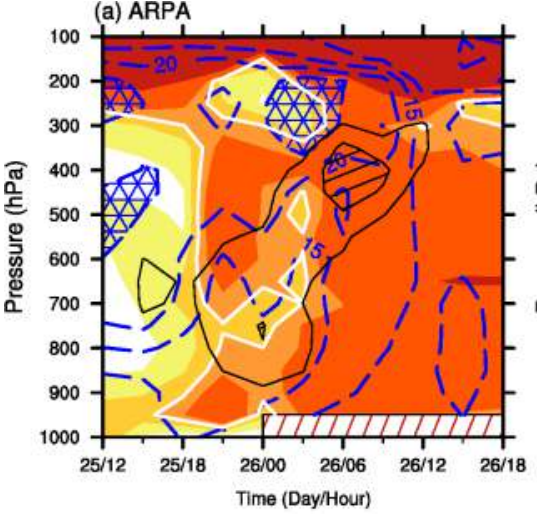

(d) ECMA

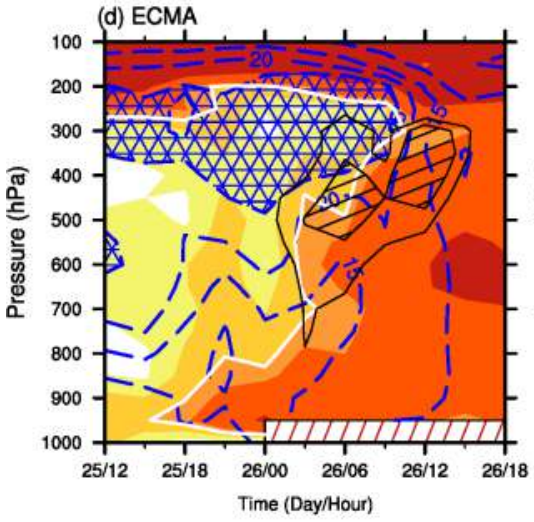

(b) ARPB

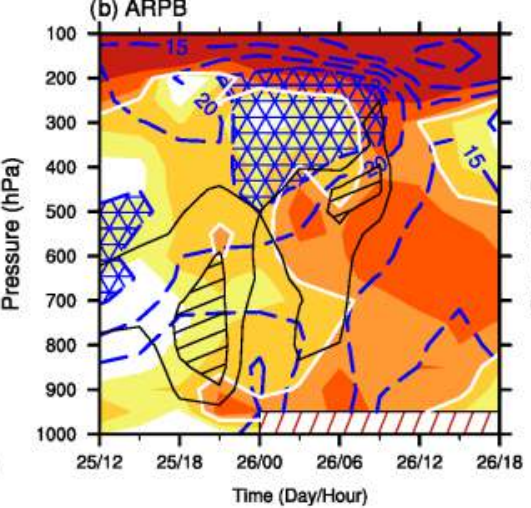

(e) ECMB

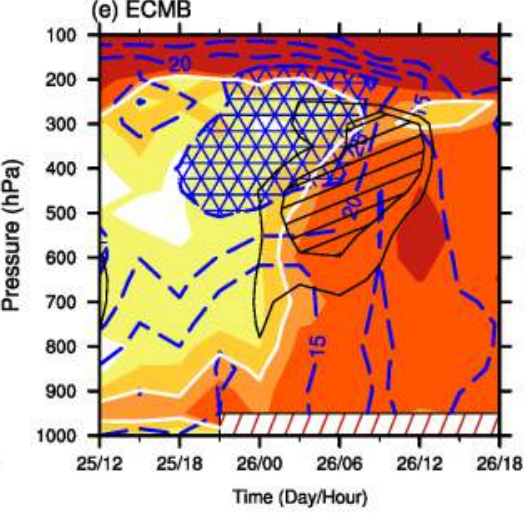

Potential Vorticity (PVU)

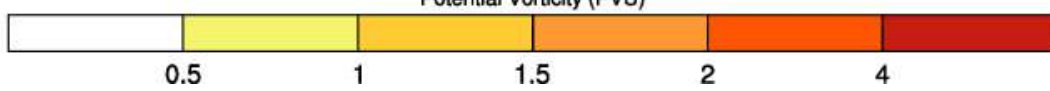

(c) ARPC

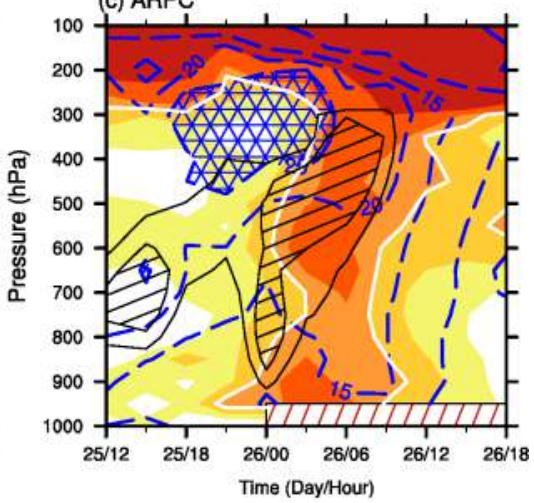

ECMC

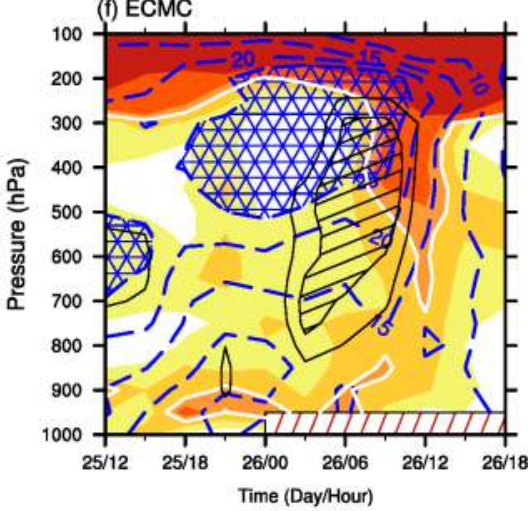

4

Figure 15. Time-pressure diagram: potential vorticity (shaded, PVU, white contour represents the 1.5 PVU surface), horizontal wind speed (dashed lines, every $5 \mathrm{~m} \mathrm{~s}^{-1}$, hatched when larger than $30 \mathrm{~m} \mathrm{~s}^{-1}$ ) and $\omega_{\text {dyn }}$ at -0.4 and $-0.3 \mathrm{~Pa} \mathrm{~s}^{-1}$ (thin black lines, hatched when less than $-0.4 \mathrm{~Pa} \mathrm{~s}$ ) for (a) ARPA, (b) ARPB, (c) ARPC, (d) ECMA, (e) ECMB and (f) ECMC. Fields are averaged within a 40 km circle centred on the mesocyclone. This figure is available in colour online at wileyonlinelibrary.com/journal/qj

left exit of the upper-level jet. The upward motion induced by the jet suggests an interaction between lower and upper levels. At 0600 UTC, ARPA, ECMA and ECMB show a wellestablished PV tower, taller than $600 \mathrm{hPa}$. It is around that time that the Meso-NH forecasts differ significantly in terms of MSLP minimum. After 0900 UTC, the medicane was away from the upper-level jet. This resulted in the gradual reduction of shear in the column-one of the key elements of the tropical transition process (Davis and Bosart, 2004). In consequence, the medicane developed fully into a tropical storm, as diagnosed in the cyclone phase space for the three successful forecasts, at 1500 and 1800 UTC only.

As the forecasts starting either from ECMWF or from ARPEGE analysis did not differ particularly in the wind speed at upper levels, this was not responsible for the unequal upward forcing in the left jet-exit region. Instead, a sufficient vertical development of the PV tower associated with the mesocyclone made the interaction stronger for the successful forecasts than for the others. The importance of the depth of the low-level core for the intensification of the medicane when the mesocyclone moved below the left jet-exit region is summarized by the evolution of the MSLP minimum with the jet crossing time (Figure 16). The latter was determined as the time when the maximum of the $300 \mathrm{hPa}$ wind speed averaged in a $40 \mathrm{~km}$ circle around the mesocyclone was reached (in consistency with Figure 15). This makes the jet crossing time uncertain by $3 \mathrm{~h}$ at most.

Until $0 \mathrm{~h}$, every forecast shows an MSLP decrease of $10 \mathrm{hPa}$ in about $12 \mathrm{~h}$, from 1008 to $998 \mathrm{hPa}$. The forecasts

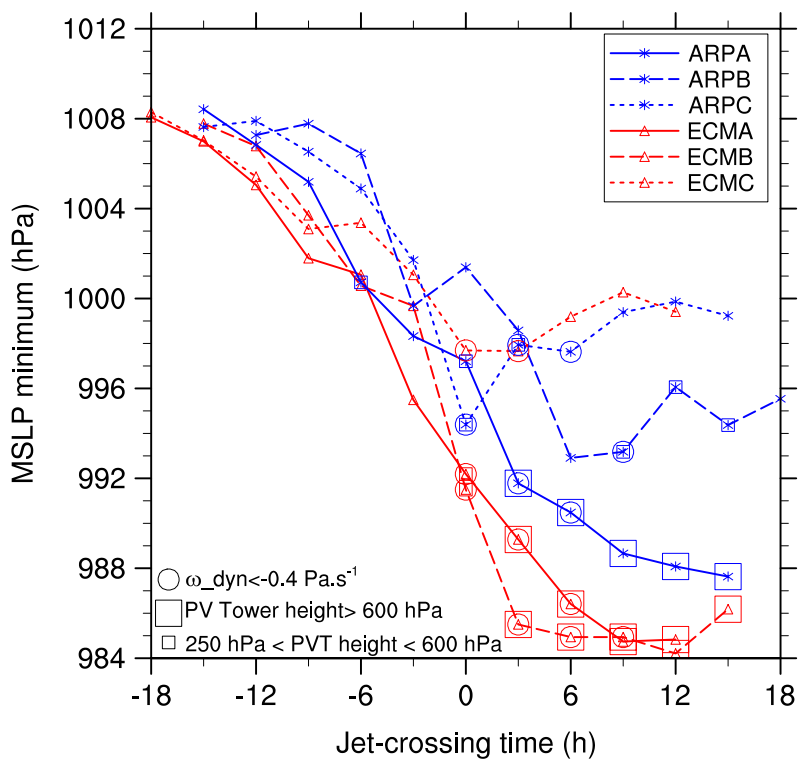

Figure 16. MSLP minimum versus the jet crossing time. Large squares indicate PV tower taller than $600 \mathrm{hPa}$, small squares $\mathrm{PV}$ tower height between 250 and $600 \mathrm{hPa}$, and circles $\omega_{\text {dyn }}$ less than $-0.4 \mathrm{~Pa} \mathrm{~s}^{-1}$. This figure is available in colour online at wileyonlinelibrary.com/journal/qj

differ substantially when crossing the upper-level jet. At $00 \mathrm{~h}$, three forecasts show a PV tower taller than $250 \mathrm{hPa}$ together with upward dynamical forcing. In ECMA and ECMB, these two conditions were sufficient for the medicane to continue 
to deepen and to develop a PV tower taller than a $600 \mathrm{hPa}$ height. In ARPA, the upward forcing at $06 \mathrm{~h}$ resulted in a rapid development of a tall PV tower. In ARPC, the medicane did not develop despite a PV tower taller than $250 \mathrm{hPa}$ and the presence of dynamical forcing. This can be explained by the track of the cyclone over land, which strongly reduced the surface latent heat flux. From 06 h, the forecasts with a less developed PV tower (ARPB and ECMC) filled up and decayed when crossing the upper-level jet. This suggests that these unsuccessful forecasts did not develop as the low-level core was not high enough to interact with the upper-level trough.

\section{Summary and discussion}

The medicane considered in this study appeared early in the morning of 26 September 2006 over the Ionian Sea and moved northeastwards, affecting Apulia, where wind gusts exceeding $40 \mathrm{~m} \mathrm{~s}^{-1}$ and an MSLP minimum of $986 \mathrm{hPa}$ were recorded (Moscatello et al., 2008a), making this case probably the deepest medicane on record (Fita et al., 2007). Documented from both the observational (Moscatello et al. 2008b; Claud et al., 2010; Conte et al., 2011) and numerical (Moscatello et al., 2008a; Davolio et al., 2009; Miglietta et al., 2011) points of view, the role of the upper-level trough on the intensification of the storm has been evaluated for the first time.

The upper-level trough was downstream of a Rossby wave perturbed by the extratropical transition of the ex-tropical cyclone Helene that started on 22 September. This resulted in very poor forecasts of the medicane and its associated trough by the ECMWF model beyond lead times of $84 \mathrm{~h}$. Work is currently under way to test whether a higher resolution would provide a better forecast of the extratropical transition of Helene and of the medicane downstream (Pantillon et al. 2011). At shorter range, the forecast skill increased with decreasing lead times. The best forecast from both ARPEGE and ECMWF was obtained when starting at 1200 UTC on 25 September, in agreement with the results of Davolio et al. (2009). At that time, the southern tip of the upper-level trough was well sampled by radiosondes launched from Tunis and Trapani. Although a PV tower built upward, suggesting the tropical transition of the medicane into a tropical storm, the low did not deepen enough. This was attributed to the low resolution of the global model (about $25 \mathrm{~km}$ ) compared to the size of the storm (a diameter of $60 \mathrm{~km})$.

The Meso-NH forecasts performed better than their global model counterparts. Three forecasts out of six reached the MSLP minimum of $986 \mathrm{hPa}$ observed on the Salentine peninsula. Comparisons with cloud cover and convective activity observed from space confirmed the good quality of the successful forecasts. The sensitivity of the Meso$\mathrm{NH}$ forecasts to the initial conditions was explained by the reduced static stability found at the southern tip of the upperlevel trough. This modified the convective activity in the vicinity of the mesocyclone during its transit over the Ionian Sea. A sufficiently vertically developed PV tower (deeper than $600 \mathrm{hPa}$ ) then made the mesocyclone deepen explosively when crossing the left jet-exit region. The resulting full tropospheric PV tower classified the medicane as a tropical storm over the Adriatic Sea.

This study underlines the forcing by the upper-level jet on the final stage of the medicane intensification and its importance on the forecast skill. This is the first time that such a mechanism has been shown for a medicane. While a deep, cut-off, cold core is usually observed at mid-upper tropospheric levels at the formation of a medicane, the upper-level jet is absent in most cases. Pytharoulis et al. (2000) discussed the potential importance of the subtropical jet in a medicane case study, but they concluded that the jet was too far away from the medicane to have promoted its evolution. In a case of explosive cyclogenesis resulting in the 40-year-record MSLP minimum of $972 \mathrm{hPa}$ over the eastern Mediterranean, the influence of a very intense upper-level jet was seen to be crucial for the intensification of the 'bomb', but not because of jet crossing. Instead, Lagouvardos et al. (2007) invoke the negative (cyclonic) tilting of the trough that forms a bulb of positive PV anomaly leading to a local destabilization of the atmosphere right above the cyclone.

The intensification of the storm as it crossed the left jetexit region was seen to be the key factor in the explosive development of Lothar, a North Atlantic storm that hit western Europe in December 1999 (Wernli et al., 2002). A vertically aligned tower of positive PV was formed from the merging of a stratospheric PV anomaly with the diabatically produced PV feature at the time of maximum storm intensity. The absence of cloud diabatic heating inhibited the rapid intensification of Lothar (Wernli et al., 2002). Although not tested here, a similar inhibition was obtained for the medicane when the latent heat release was switched off in sensitivity experiments (Moscatello et al., 2008a; Davolio et al., 2009).

It would be interesting to evaluate the role of the upperlevel jet using a PV inversion technique as in Argence et al. (2009), for example. However, modifying the upperlevel trough would change the triggering of convection; hence the development of the medicane over the Ionian Sea before its passage below the upper-level jet. Therefore, the task of evaluating the role of the upper-level trough with respect to convection would be difficult. Furthermore, convection triggered over sea is often difficult to predict accurately in the short term (e.g. Clark and Chaboureau, 2010). Perturbation studies could be conducted to look at the sensitivity of the medicane predictability to the representation of these key elements.

\section{Acknowledgement}

The authors thank Gwénaëlle Paque for her preliminary results, which inspired the present work, Jean-Pierre Cammas for the use of the $\mathrm{AB}$ omega inversion code, and the anonymous referees for their constructive comments. This study was sponsored by the French Ministry of Research through project ANR-VMC2007 'Forecast and projection in climate scenario of Mediterranean intense events: Uncertainties and Propagation on environment' (MedUP) and by the Institut National des Sciences de l'Univers through the EPIGONE project. Florian Pantillon was supported by a CNRS and Météo-France $\mathrm{PhD}$ grant. Computer resources were allocated by GENCI (project 90569). MSG observations were obtained from SATMOS. AMSU data were obtained through the French Mixed Service Unit ICARE. QuikScat data are produced by Remote Sensing Systems and sponsored by the NASA Ocean Vector Winds Science Team. 


\section{References}

Anwender D, Harr PA, Jones SC. 2008. Predictability associated with the downstream impacts of the extratropical transition of tropical cyclones: case studies. Mon. Weather Rev. 136: 3226-3247.

Argence S, Lambert D, Richard E, Chaboureau JP, Söhne N. 2008. Impact of initial conditions uncertainties on the predictability of heavy rainfall in the Mediterranean: a case study. Q. J. R. Meteorol. Soc. 134: 1775-1788.

Argence S, Lambert D, Richard E, Chaboureau JP, Arbogast P, Maynard K. 2009. Improving the numerical prediction of a cyclone in the Mediterranean by local potential vorticity modifications. Q. J. R. Meteorol. Soc. 135: 865-879.

Bechtold P, Bazile E, Guichard F, Mascart P, Richard E. 2001. A mass flux convection scheme for regional and global models. Q. J. R. Meteorol. Soc. 127: 869-886.

Campins J, Jansà A, Genovés A. 2006. Three-dimensional structure of western Mediterranean cyclones. Int. J. Climatol. 26: 323-343.

Chaboureau JP, Bechtold P. 2002. A simple cloud parameterization derived from cloud resolving model data: diagnostic and prognostic applications. J. Atmos. Sci. 59: 2362-2372.

Chaboureau JP, Bechtold P. 2005. Statistical representation of clouds in a regional model and the impact on the diurnal cycle of convection during tropical convection, cirrus and nitrogen oxides (TROCCINOX). J. Geophys. Res. 110: D17103, DOI: 10.1029/ 2004 JD005645.

Chaboureau JP, Claud C. 2006. Satellite-based climatology of Mediterranean cloud systems and their association with largescale circulation. J. Geophys. Res. 111: D01102, DOI: 10.1029/2005 JD006460.

Chaboureau JP, Pinty JP. 2006. Validation of a cirrus parameterization with Meteosat Second Generation observations. Geophys. Res. Lett. 33: L03815, DOI: 10.1029/2005GL024725.

Chaboureau JP, Söhne N, Pinty JP, Meirold-Mautner I, Defer E, Prigent C, Pardo JR, Mech M, Crewell S. 2008. A midlatitude cloud database validated with satellite observations. J. Appl. Meteorol. Climatol. 47: 1337-1353.

Clark H, Chaboureau JP. 2010. Uncertainties in short-term forecasts of a Mediterranean heavy precipitation event: assessment with satellite observations. J. Geophys. Res. 115: D22213, DOI: 10.1029/2010 JD014388.

Claud C, Alahmmoud B, Funatsu BM, Chaboureau JP. 2010. Mediterranean hurricanes: large-scale environment and convective and precipitating areas from satellite microwave observations. Nat. Hazards Earth Syst. Sci. 10: 2199-2213.

Conte D, Miglietta MM, Levizzani V. 2011. Analysis of instability indices during the development of a Mediterranean tropical-like cyclone using MSG-SEVIRI products and the LAPS model. Atmos. Res. 101: $264-279$.

Cuxart J, Bougeault P, Redelsperger JL. 2000. A turbulence scheme allowing for mesoscale and large-eddy simulations. Q. J. R. Meteorol. Soc. 126: 1-30.

Davies-Jones R. 1991. The frontogenetical forcing of secondary circulations. Part I: The duality and generalization of the Q vector. J. Atmos. Sci. 48: 497-509.

Davis CA, Bosart LF. 2004. The TT problem. Bull. Am. Meteorol. Soc. 85: $1657-1662$

Davolio S, Miglietta MM, Moscatello A, Pacifico F, Buzzi A, Rotunno R. 2009. Numerical forecast and analysis of a tropical-like cyclone in the Ionian Sea. Nat. Hazards Earth Syst. Sci. 9: 551-562.

Fita L, Romero R, Luque A, Emanuel K, Ramis C. 2007. Analysis of the environments of seven Mediterranean tropical-like storms using an axisymmetric, nonhydrostatic, cloud resolving model. Nat. Hazards Earth Syst. Sci. 7: 41-56.

Funatsu BM, Claud C, Chaboureau JP. 2007. Potential of Advanced Microwave Sounding Unit to identify precipitating systems and associated upper-level features in the Mediterranean region: case studies. J. Geophys. Res. 112: D17113, DOI: 10.1029/2006JD008297.

Funatsu BM, Claud C, Chaboureau JP. 2009. Comparison between the large-scale environment of moderate and intense precipitating systems in the Mediterranean region. Mon. Weather Rev. 137: 3933-3959.

Gregory D, Morcrette JJ, Jakob C, Beljaars AM, Stockdale T. 2000. Revision of convection, radiation and cloud schemes in the ECMWF model. Q. J. R. Meteorol. Soc. 126: 1685-1710.

Harr PA, Anwender D, Jones SC. 2008. Predictability associated with the downstream impacts of the extratropical transition of tropical cyclones: methodology and a case study of Typhoon Nabi (2005). Mon. Weather Rev. 136: 3205-3225.

Hart RE. 2003. A cyclone phase space derived from thermal wind and thermal asymmetry. Mon. Weather Rev. 131: 585-616.
Homar V, Romero R, Stensrud D, Ramis C, Alonso S. 2003. Numerical diagnosis of a small, quasi-tropical cyclone over the western Mediterranean: dynamical vs. boundary factors. Q. J. R. Meteorol. Soc. 129: 1469-1490.

Jones SC, Harr PA, Abraham J, Bosart LF, Bowyer PJ, Evans JL, Hanley DE, Hanstrum BN, Hart RE, Lalaurette F, Sinclair MR, Smith RK, Thorncroft C. 2003. The extratropical transition of tropical cyclones: forecast challenges, current understanding, and future directions. Weather Forecast. 18: 1052-1092.

Lafore JP, Stein J, Asencio N, Bougeault P, Ducrocq V, Duron J, Fischer C, Héreil P, Mascart P, Masson V, Pinty JP, Redelsperger JL, Richard E, Vilà-Guerau de Arellano J. 1998. The Meso-NH Atmospheric Simulation System. Part I: Adiabatic formulation and control simulations. Scientific objectives and experimental design. Ann. Geophys. 16: 90-109.

Lagouvardos K, Kotroni V, Nickovic S, Jovic D, Kallos G. 1999. Observations and model simulations of a winter sub-synoptic vortex over the central Mediterranean. Meteorol. Appl. 6: 371-383.

Lagouvardos K, Kotroni V, Defer E. 2007. The 21-22 January 2004 explosive cyclogenesis over the Aegean Sea: observations and model analysis. Q. J. R. Meteorol. Soc. 133: 1519-1531.

Laviola S, Miglietta MM, Levizzani V. 2011. Satellite and numerical model investigation of two mesoscale convective systems over central Mediterranean. J. Hydrometeorol. 12: 634-649.

Mallet I, Cammas JP, Mascart P, Bechtold P. 1999. Effects of cloud diabatic heating on the early development of the FASTEX IOP17 cyclone. Q. J. R. Meteorol. Soc. 125: 3439-3467.

McTaggart-Cowan R, Galarneau RJ Jr, Bosart LF, Milbrandt JA. 2010. Development and tropical transition of an Alpine lee cyclone. Part I: Case analysis and evaluation of numerical guidance. Mon. Weather Rev. 138: 2281-2307.

Meirold-Mautner I, Prigent C, Defer E, Pardo JR, Chaboureau JP, Pinty JP, Mech M, Crewell S. 2007. Radiative transfer simulations using mesoscale cloud model outputs: comparisons with passive microwave and infrared satellite observations for mid-latitudes. $J$. Atmos. Sci. 64: 1550-1568.

Miglietta MM, Moscatello A, Conte D, Mannarini G, Lacorata G, Rotunno R. 2011. Numerical analysis of a Mediterranean 'hurricane' over south-eastern Italy: sensitivity experiments to sea surface temperature. Atmos. Res. 101: 412-426.

Mlawer EJ, Taubman SJ, Brown PD, Iacono MJ, Clough SA. 1997. Radiative transfer for inhomogeneous atmospheres: RRTM, a validated correlated-k model for the longwave. J. Geophys. Res. 102D: 16663-16682.

Moscatello A, Miglietta MM, Rotunno R. 2008a. Numerical analysis of a Mediterranean 'hurricane' over southeastern Italy. Mon. Weather Rev. 136: 4373-4397.

Moscatello A, Miglietta MM, Rotunno R. 2008b. Observational analysis of a Mediterranean 'hurricane' over southeastern Italy. Weather 63: 306-311.

Noilhan J, Planton S. 1989. A simple parameterization of land surface processes for meteorological models. Mon. Weather Rev. 117: 536-549.

Pantillon F, Mascart P, Chaboureau JP, Lac C, Escobar J, Duron J. 2011. Seamless MESO-NH modeling over very large grids. C. R. Mecanique 339: $136-140$.

Pinty JP, Jabouille P. 1998. A mixed-phase cloud parameterization for use in a mesoscale non-hydrostatic model: simulations of a squall line and of orographic precipitations. In Conference on Cloud Physics. American Meteorological Society: Everett, WA; 217-220.

Pyle ME, Keyser D, Bosart LF. 2004. Diagnostic study of jet streaks: kinematic signatures and relationship to coherent tropopause disturbances. Mon. Weather Rev. 132: 297-319.

Pytharoulis I, Craig GC, Ballard S. 2000. The hurricane-like Mediterranean cyclone of January 1995. Meteorol. Appl. 7: 261-279.

Reale O, Atlas R. 2001. Tropical cyclone-like vortices in the extratropics: observational evidence and synoptic analysis. Weather Forecast. 16: 7-34.

Riemer M, Jones SC. 2010. Downstream impact of tropical cyclones on a developing baroclinic wave in idealized scenarios of extratropical transition. Q. J. R. Meteorol. Soc. 136: 617-637.

Riemer M, Jones SC, Davis CA. 2008. The impact of extratropical transition on the downstream flow: An idealized modelling study with a straight jet. Q. J. R. Meteorol. Soc. 134: 69-91.

Sanders F, Gyakum JR. 1980. Synoptic-dynamic climatology of the 'bomb'. Mon. Weather Rev. 108: 1589-1606.

Söhne N, Chaboureau JP, Guichard F. 2008. Verification of cloud cover forecast with satellite observation over West Africa. Mon. Weather Rev. 136: 4421-4434. 
Stein J, Richard E, Lafore JP, Pinty JP, Asencio N, Cosma S. 2000 High-resolution non-hydrostatic simulations of flash-flood episodes with grid-nesting and ice-phase parameterization. Meteorol. Atmos. Phys. 72: 203-221.

Uccellini LW. 1986. The possible influence of upstream upper-level baroclinic processes on the development of the QE II storm. Mon. Weather Rev. 114: 1019-1027.

Wernli H, Dirren S, Liniger MA, Zillig M. 2002. Dynamical aspects of the life cycle of the winter storm 'Lothar' (24-26 December 1999). Q. J. R. Meteorol. Soc. 128: 405-429. 